\title{
From static alteration to mylonitization: a nano- to micrometric study of chloritization in granitoids with implications for equilibrium and percolation length scales
}

\author{
Laura Airaghi $^{1,2}{ }^{*}$, Benoit Dubacq ${ }^{1}$, Anne Verlaguet ${ }^{1}$, Franck Bourdelle ${ }^{3}$, Nicolas Bellahsen ${ }^{1}$, \\ Alexandre Gloter ${ }^{4}$
}

\author{
${ }^{1}$ Sorbonne Université, CNRS-INSU, Institut des Sciences de la Terre de Paris, ISTeP UMR 7193, F- \\ 75005 Paris, France \\ ${ }^{2}$ Université of Orléans, CNRS, BRGM, ISTO, UMR 7327, F-45071, Orléans, France \\ ${ }^{3}$ Univ. Lille, IMT Lille Douai, Univ. Artois, Yncrea Hauts-de-France, ULR 4515 - LGCgE, \\ Laboratoire de Génie Civil et géo-Environnement, F-59000 Lille, France \\ ${ }^{4}$ Laboratoire de Physique du Solide, CNRS, Université Paris-Saclay, 91405 Orsay, France \\ *now at: Université of Orléans, CNRS, BRGM, ISTO, UMR 7327, F-45071, Orléans, France \\ corresponding author: laura.airaghi@univ-orleans.fr \\ ORCID: https://orcid.org/0000-0001-7032-2732
}

Key words: greenschist-facies, $\mathrm{XFe}^{3+}$ chlorite, TEM, Bielsa, Pyrenees, hydrothermal alteration

\begin{abstract}
Strain accommodation in upper crustal rocks is often accompanied by fluid-mediated crystallization of phyllosilicates, which influence rock strength and shear zone formation. The composition of these phyllosilicates is frequently used for pressure-temperature-time constraints of deformation events, although it is often highly heterogeneous, even in mylonites. This study investigates the reactions producing a phyllosilicate, chlorite, in and below grenschist-facies conditions and the variations in chlorite composition along a strain gradient in the Variscan Bielsa granitoid (Axial Zone, Pyrenees). Compositional maps of chlorite including iron speciation are compared to nanostructures observed by transmission electron microscopy in increasingly-strained samples and related to mechanisms of fluid percolation. In the Bielsa granitoid, altered at the late Variscan, Alpine-age shear zones are found with high strain gradients. The undeformed granitoid exhibits local equilibria, pseudomorphic replacement and high compositional heterogeneities in chlorite. This is attributed to variable reaction mechanisms at nanoscale and element supply, little interconnected intra- and inter-grain nanoporosity and isolation of fluid evolving in local reservoirs. In samples with discrete and $\mathrm{mm}$-sized fractures, channelized fluid triggered the precipitation of homogeneous Alpine chlorite in fractures, preserving late-Variscan chlorite within the matrix. In low-grade mylonites, where brittle-ductile deformation is observed, micro and nanocracks and defects allows the fluid percolating into the matrix at the scale of hundreds of $\mu \mathrm{m}$. This results in a more pervasive but incomplete replacement of late-Variscan chlorite by Alpine chlorite, despite the high strain. In studied granitoids deformed under greenschist-facies conditions, local equilibria and high compositional heterogeneities in phyllosilicates as chlorite are therefore preserved according reaction mechanisms and element mobility controlled by (i) matrix-fracture porosity contrasts at nanoscale and (ii) the location and interconnection of nanoporosity between crystallites of phyllosilicates. This preservation influences our ability to reconstruct the pre- and syn-kinematic metamorphic history of granitic rocks in low-grade units of orogens.
\end{abstract}

\section{INTRODUCTION}

Zones of strain localization in the upper continental crust show evidence, in many geological contexts, of fluid-mediated mineral reactions synchronous with deformation, commonly involving crystallization of phyllosilicates (e.g. Ingles et al. 1999; Goncalves et al. 2012; Oliot et al. 2010; Rolland and Rossi 2016; Wehrens et al. 2017). 
Phyllosilicates contain indeed abundant $\mathrm{H}_{2} \mathrm{O}$ in their structure (e.g. 2-3 wt.\% for biotite, 4-5 wt.\% for phengite, $\sim 12 \mathrm{wt} . \%$ for chlorite and serpentine, and up to $35 \mathrm{wt}$. \% for some hydrated smectites). The growth of phyllosilicates is of primary importance for deformation of nominally anhydrous or little-hydrated silicate rocks as phyllosilicates dramatically soften rocks when interconnected (e.g. Wintsh et al. 1995; Wibberly and McCaig 2000; Gueydan et al. 2003; Marsh et al. 2009), often leading to the development of shear zones possibly via precursors (Pennacchioni and Mancktelow, 2018, among others). How fluids circulate during early stages of fluid-rock interactions and with increasing deformation remains however unclear, as well as how changing fluidrock ratios affect deformation, metamorphic reactions and their mineral record.

Reaction-induced porosity (Putnis and Austrheim 2010; Putnis and John,2010; Plümper et al. 2017) and fracturing before or during ductile flow have been proposed as mechanisms of fluids percolation, triggering softening reactions (e.g. Pennacchioni and Mancktelow, 2007; Pec et al., 2012; Wherens et al. 2017; Berger et al., 2017; Bellahsen et al. 2019; Leydier et al., 2019). Additional information on fluid circulation mechanisms may be obtained from the compositional and microstructural study of phyllosilicates. For example, the distribution of phyllosilicates allows reconstructing syn-kinematic fluid circulation at outcrop scale (e.g. Maggi et al. 2014) while phyllosilicate composition is commonly used to constrain the pressuretemperature-time evolution of shear zone formation (Rolland et al. 2008, 2009; Abd Elmola 2017; Sanchez et al. 2011). Variations in phyllosilicate composition may reflect changes in fluid sources, local fluid heterogeneity (e.g. McWilliams et al. 2007; Berger et al., 2017), reactions limited by fluid availability as for partial mineral replacement (e.g. Parra et al. 2002; Jamtveit and Austrheim 2010; Putnis and Austrheim 2010; Airaghi et al. 2017a) and local heterogeneities in differential stress linked to differences in chemical potentials (e.g. Wheeler, 2014; Moore et al., 2019).

In practice, the composition of phyllosilicates crystallizing at upper crustal conditions (below $\sim 450^{\circ} \mathrm{C}$ ) is often heterogeneous down to micrometer- and nanometer-scale (Williams et al. 2001; Airaghi et al. 2017a,b; Airaghi et al. 2018; Vidal et al. 2006; Bourdelle et al. 2018; Scheffer et al. 2016). In shear zones formed in the presence of fluid, the composition of phyllosilicates such as white mica and chlorite may show complete reequilibration (Rolland et al. 2008; Sanchez et al. 2011; Airaghi et al. 2017b) or preserve compositional heterogeneities despite high strain (Berger et al. 2017, Abd Elmola et al. 2017; Airaghi et al. 2020). The reasons for these differences remain unclear as upscaling and downscaling are difficult. Many studies investigated reaction mechanisms involving phyllosilicates in granitic rocks down to nanoscale (e.g. for chlorite and biotite, Veblen and Ferry, 1983; Banfield and Eggleton 1988; Aspandiar and Eggleton 2002), yet paying less attention to upscaling to microscale compositional variations. Other studies explored in details mineral reactions and their mass balance (e.g. Parry and Downey 1982; Nishimoto and Yoshida 2010; Morad et al. 2011) without linking them to nanostructures. Upscaling the effects of nanometric features to micrometric composition variations appears crucial to constrain fluid percolation mechanisms in initially anhydrous rocks and phyllosilicate-rich shear zones, as well as to understand the metamorphic record such as found in the crystalline basement of orogens.

This study investigates the relationship between microscale and nanoscale compositional heterogeneities and structures of phyllosilicate-bearing greenschist-facies mineral assemblages in a series of variably deformed metagranitoids of the Axial zone, in central-western Pyrenees. These rocks experienced multiple fluid-rock interaction events: a first event of hydrothermal alteration at the late-Variscan (pre-kinematic) and a second one accompanied by deformation at Alpine times (Airaghi et al. 2020; Bellahsen et al. 2019). This study is focussed on chlorite as the chloritization of granite is one of the dominant processes during hydrothermal alteration and fracturing of crystalline basement rocks (e.g. Schmidt et al. 2018). Mechanisms of chloritization are well described (e.g. Veblen and Ferry, 1983; Banfield and Eggleton 1988; Aspandiar and Eggleton, 2002; Yuguchi et al. 2015), and chlorite is often used to estimate the temperature at which crustal shear zones 
develop. However, the crystal chemistry of chlorite is difficult to assess, in particular because chlorite may incorporate significant $\mathrm{Fe}^{3+}$ and show vacant sites, complicating estimations of structural formulae (e.g., Vidal et al. 2006; De Andrade et al. 2011; Trincal and Lanari 2016; Masci et al. 2019). Here the chemical composition of chlorite has been analysed by scanning electron microscopy, electron microprobe, scanning transmission $\mathrm{X}$ -

\section{GEOLOGICAL SETTING AND SAMPLING}

The studied metagranitoid series is located in the Axial zone of the Pyrenees, part of Sverging tectonic units stacked during the Late Cretaceous-Early Miocene collision of the Iberian and European plates (Figure 1a). The crystalline basement of the Axial zone mainly consists of plutons (i.e. Bielsa, Néouvielle, Maladetta massifs etc., Figure 1a, b) emplaced into Paleozoic sediments during late-Variscan times (320-300 Ma, e.g. Paquette et al. 1997). The study area is located in the Bielsa pluton, within the Bielsa unit, structurally located between the S-verging Gavarnie and Guarga thrusts (Figure 1b, Román-Berdiel et al. 2004). The pluton was pervasively altered in greenschist-facies conditions in late-post Variscan time (230-300 Ma, Airaghi et al. 2020). A second alteration event in lower greenschist-facies conditions took place at $\sim 40$ Ma (Alpine compressional phase) and was ray microscopy using synchrotron radiation and electron energy loss spectroscopy. Nanostructures have been observed by transmission electron microscopy. This approach allows estimating lengthscales for element mobility and equilibrium, and discussing the mechanisms of fluid percolation and their signature in terms of mineral assemblage.

associated to shearing and fracturing (Bellahsen et al. 2019; Airaghi et al. 2020). Pre- and synAlpine alteration caused a massive production of phyllosilicates (white mica and chlorite), softening the protolith. Deformation now appears distributed at the scale of the massif, with meter to decameter-thick shear zones spaced of less than $200 \mathrm{~m}$ (Fig. 1c; Bellahsen et al. 2019). Mylonites in shear zones alternate with areas where the granitoid is fractured, little deformed or undeformed.

Samples were selected from series collected along decameter-scale sections in the Bielsa granitoid (Fig. 1b and c). At sample scale, metamorphic chlorite and white mica show high compositional variability and partial replacement. At least two generations of chlorite were identified by Airaghi et al. (2020), with crystallization temperatures of $300-350^{\circ} \mathrm{C}$ (Chl1, late to post-Variscan hydrothermal alteration) and $\sim 280^{\circ} \mathrm{C} \quad(\mathrm{Chl} 2, \quad$ Alpine deformation event).

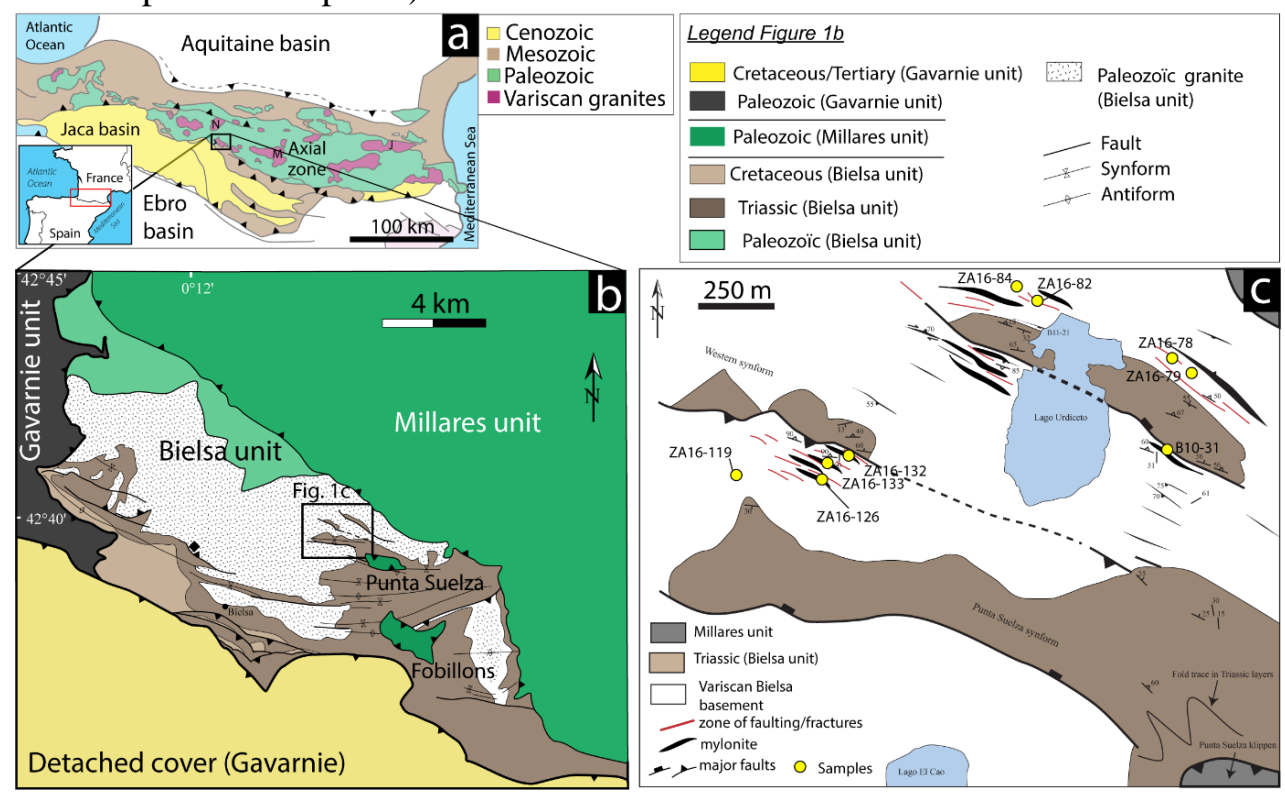

Figure 1. Geology of the studied area. (a) Schematic structural map of the Pyrenees, modified from RománBerdiel et al. (2004). Black square: Bielsa, N: Néouvielle, M: Maladeta, J: Jau. (b) Structural map of the Bielsa 
unit. (c) Structural map of the area of the Lake of Urdiceto in the Bielsa massif where samples were collected (modified from Bellahsen et al. 2019).

\section{SAMPLE PREPARATION AND ANALYTICAL METHODS}

Mineral abundances were obtained by counting 500 points on thin section scans with JMicroVision v1.2.7 (www.jmicrovision.com). Quantitative point analyses of biotite, amphibole and chlorite were acquired with a CAMECA SX-Five electron probe microanalyser (EPMA) at CAMPARIS (Sorbonne University). Point measurements were made under a $15 \mathrm{kV}$ acceleration voltage and $10 \mathrm{nA}$ beam current with a $\sim 1 \mu \mathrm{m}$ beam size, in wavelength-dispersive spectroscopy (WDS) mode, using diopside $(\mathrm{Ca}, \mathrm{Mg}, \mathrm{Si}), \mathrm{MnTiO}_{3}$ $(\mathrm{Mn}, \mathrm{Ti})$, orthoclase $(\mathrm{K}, \mathrm{Al})$, hematite $(\mathrm{Fe})$, albite (Na) and $\mathrm{Cr}_{2} \mathrm{O}_{3}(\mathrm{Cr})$ as standards for measuring the elements written in parentheses. EPMA element maps were acquired in WDS mode at $100 \mathrm{nA}$ beam current, $15 \mathrm{keV}$ acceleration voltage with a $200 \mathrm{~ms}$ dwell time. All EPMA data were quantified with the PAP procedure (Pouchou and Pichoir, 1991). Scanning electron microscope (SEM) element maps were acquired with a SUPRA-55VP SEM at ISTeP (Sorbonne Université, Paris) in energy-dispersive spectroscopy (EDS) mode at $15 \mathrm{keV}$ acceleration voltage, $30 \mathrm{nA}$ beam current with a dwell time of $256 \mu$ s. SEM element maps of chlorite were converted to oxide wt.\% and processed with the software XMAPToOLS 2.4. (Lanari et al. 2014, 2019). XMAPTOOLS was also used to estimate the proportion of mineral groups based on composition (see Supplementary Material). In order to use transmission microscopy on preserved-texture crystallites, eight ultra-thin foils of $10 \mu \mathrm{m} \times 5 \mu \mathrm{m} \times 80 \mathrm{~nm}$ in size were cut from thin sections by focused ion beam (FIB) microscope (FEI strata DualBeam 235) at the Institut d'Electronique, de Microélectronique et de Nanotechnologie (IEMN, Lille, France). The first step of the milling - rough excavations from both sides of the section - was completed using a $30 \mathrm{kV} \mathrm{Ga}^{+}$beam operating at $5 \mathrm{nA}$. After transfer of each pre-cut section on a TEM grid, fine thinning was performed with a $<100 \mathrm{pA}$ current beam, followed by low-tension cleaning (3 $\mathrm{kV}$ ) avoiding amorphisation of the crystallites.

Images at the (scanning) transmission electron microscope ((S)TEM) were acquired on FIB foils at the Laboratoire de Physique des Solides (LPS, Orsay, France), with a Nion USTEM200 instrument operated at $100 \mathrm{keV}$. Images were acquired in dark field (DF), bright field (BF) and annular bright field (ABF) with a current of $\sim 10 \mathrm{pA}$ and an average field of view of $256 \mathrm{~nm}^{2}$ giving a dose rate of $\sim 1000$ electrons per $\mathrm{nm}^{2}$ per second. Images were obtained with typical scanning time of 40 seconds. Additional TEM images were acquired at the Laboratoire des Interfaces, Confinement, Matériels et Nanostructures (ICMN) of Orléans (France) with an ARM CFEG Jeol instrument, at $200 \mathrm{kV}$ and a dose rate lower than $30 \mathrm{pA} / \mathrm{cm}^{2}$. (S)TEM images were processed with the software Gatan Digital Micrograph 2.32.888, 1996-2015 (www.gatan.com). Iron speciation has been obtained in situ around the $\mathrm{L}_{2,3}$-edges using both electron energy loss spectroscopy (EELS) with TEM (at LPS) and X-ray Absorption Near Edge Structure Spectroscopy (XANES) by scanning transmission X-ray microscopy (STXM). EELS data were acquired over areas (150 up to 500 $\mathrm{nm}^{2}$ ) in scanning mode with a beam current of $100-150 \mathrm{pA}$. One analysis is comprised of 50 scans of $1 \mathrm{~s}$ each. Sample damaging from electrons was checked by monitoring the time evolution of the spectra, showing increasing $\mathrm{Fe}^{3+} / \mathrm{Fe}^{2+}$ ratios after a variable analysis time, typically around $15 \mathrm{~s}$. Only initial ratios are reported here. XANES spectra were acquired with STXM on the PolLux beamline, at the Synchrotron Light Source of the Paul Sherrer Institute, Villigen (Switzerland). The SLS synchrotron storage ring operated at $2.4 \mathrm{GeV}$ and $400 \mathrm{~mA}$ current in a top-up mode during data collection. For details on beamline characteristics, see Raabe et al. (2008). Spectra were recorded in transmission mode over the 690-730 eV energy range ( $\mathrm{Fe} \mathrm{L}_{2,3}$-edge) with a $0.2 \mathrm{eV}$ spectral resolution. The dwell time per pixel and energy point was between 1.5 and 3 ms. Values and maps of $\mathrm{Fe}^{3+} / \mathrm{Fe}_{\mathrm{TO}}$ ratio (below noted $\mathrm{XFe}^{3+}$ ) for chlorite, biotite and amphibole, were obtained from EELS spectra, STXM linescan spectra and STXM image stacks, following the procedure of Bourdelle et al. (2013). An energy correction of $-1.7 \mathrm{eV}$ was applied for spectra acquired by STXM after calibration, while energy correction for spectra acquired by EELS was performed by setting the $\mathrm{L}_{2 \text {-a }}$ peak energy value at $721 \mathrm{eV}$ (ensuring that 
$\mathrm{L}_{3-\mathrm{a}}$ iron peak was at $\sim 708 \mathrm{eV}$ ). This correction turns out to be optimal for relatively low $\mathrm{XFe}^{3+}$ ratios (up to 20\%) but causes larger uncertainties for higher $\mathrm{XFe}^{3+}$.

\section{$4 . \quad$ PETROGRAPHY MICROSTRUCTURES}

AND

Nine samples were selected for this study among twenty-seven samples collected along an E-W transect of the Bielsa massif (documented in detail by Airaghi et al. 2020). Selection criteria were based on optimal representation of the evolution of

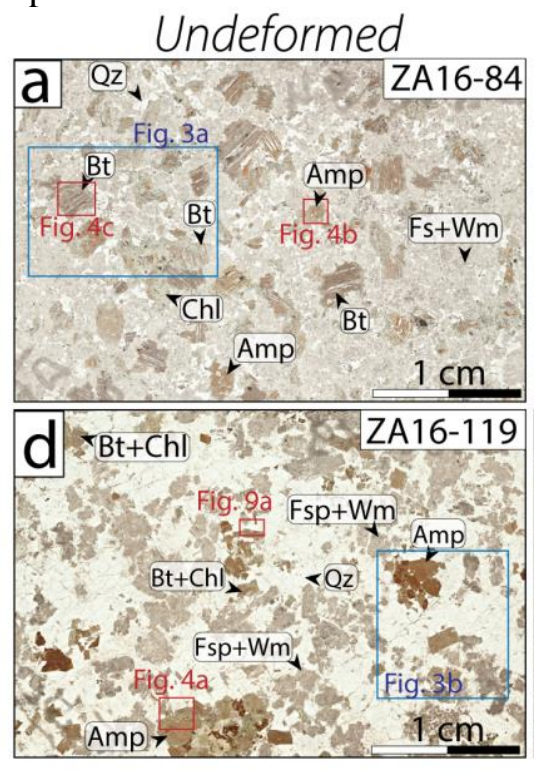

microstructures, metamorphic reactions and compositional variations in chlorite. The set comprises (i) undeformed (ZA16-84, ZA16119) and little deformed (ZA16-79) granitoids (Figure 2a, d), (ii) discretely deformed rocks (ZA16-78, ZA16-82, ZA16-132 Fig. 2b, e) and (iii) mylonites (ZA16-133, B10-31, ZA16-126 Fig. 2c, f). In the following, only petrological and textural features relevant to the link between mineral replacement, nano and microstructures are reported, starting with undeformed granites and granodiorites and ending with mylonites.

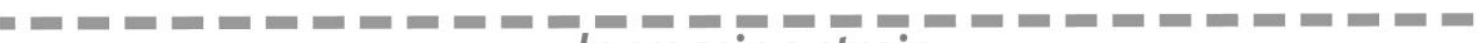

\section{Increasing strain}

Figure 2. Thin section micrographs of six representative samples increasingly deformed. Mineral abbreviations are from Whitney and Evans (2010) except for Wm = white mica. S: schistosity, C: shear planes.

Samples of undeformed rocks exhibit magmatic textures with euhedral mineral shapes (Fig. 2a, d, 3a-c). Average proportions of major minerals forming the magmatic assemblage are: biotite ( 15 vol.\%), amphibole $(\sim 7-15$ vol.\%), zoned plagioclase and Kfeldspar ( 41-50 vol.\%), quartz (17-27 vol. \%). Plagioclase breaks down to micrometric grains of albite + calcite \pm rare epidote (Fig. $4 a, b, 5 a$ and Fig. S4d in Supplementary Material) while K-feldspar $\quad(\sim 1 \mathrm{~mm}$ in size $)$ is pseudomorphically replaced at $60 \%$ by aggregates of white mica $(10-30 \mu \mathrm{m}$ in size $)+$ albite (Figure 3a, c) with spongy, porous textures (Fig. 4d, 5b). Both mineral transformations result in porosity formation and a two-orders-of-magnitude grain size reduction (e.g. Fig. 4a-d). Quartz appears as millimetric grains, with rare cracks, a slightly irregular extinction and rare and sparse micrometric fluid inclusions (Fig. 3b, c, 4a, b, d). Magmatic amphibole from $1 \mathrm{~mm}$ to $500 \mu \mathrm{m}$ long is chloritized between 10\% (ZA16-119, Fig. 2d, 3b) and $40 \%$ (ZA16-84, Fig. 2a, 3a) along cleavage planes and at grain boundaries mainly with biotite and altered plagioclase (Fig. 4a-c, $5 \mathrm{~d}, \mathrm{~g})$. Amphibole chloritization is less intense when adjacent to magmatic quartz and $\mathrm{K}$ feldspar (e.g. Fig. 4a). The boundary between amphibole and chlorite is sharp. Biotite grains (with ilmenite inclusions) are transformed at 70-90 \% to chlorite \pm prehnite \pm quartz + a Tibearing phase (anatase or titanite) \pm apatite (Figure 3a, 4a and c). White mica (20-100 $\mu \mathrm{m}$ long) is also observed associated to chlorite (e.g. Fig. 6b and Fig. S4d in the Supplementary 
Material). Chloritization occurs as inserts along biotite cleavages and at the contact among biotite, amphibole and plagioclase, showing then a sharp contact with biotite (Fig. 4a, c and $5 \mathrm{~d}, \mathrm{e}, \mathrm{g}, \mathrm{h})$. In the following, chlorite forming flakes after biotite and amphibole pseudomorphs is named Chl1. Chloritization results in phase mixture and grain size reduction for both amphibole and biotite (product size varying from $10 \mu \mathrm{m}$ to $200 \mu \mathrm{m}$ ). When secondary quartz is associated to biotite breakdown, it forms micrometric bands, elongated parallel to the biotite cleavage in biotite pseudomorphs (Fig. 4c, d) or 10-50 $\mu \mathrm{m}$ grains rimming biotite/ amphibole boundaries (Fig. 4c, 5g).

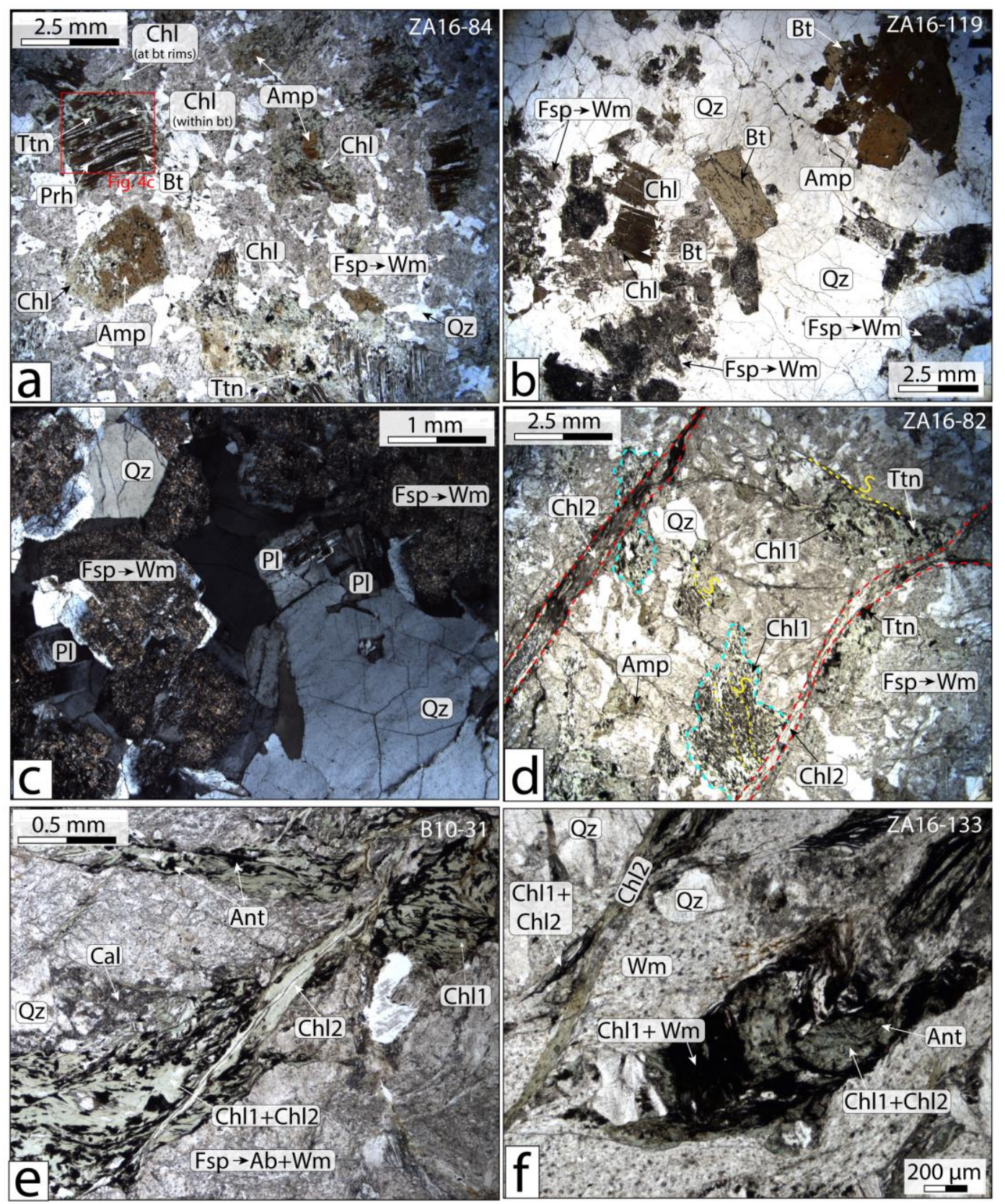

Figure 3 Photomicrographs of samples under natural and crossed polars light. (a) Undeformed, altered granodiorite ZA16-84. (b) Undeformed, altered granodiorite ZA16-119. (c) Microcracks in magmatic quartz and sericitization of feldspar in undeformed granodiorite ZA16-84. (d) Discrete mm-size fractures filled with Chl2 and offsetting Chl1 flakes defining S in sample ZA16-82. Red: fractures, blue: chlorite flakes, yellow: schistosity. (e) Crack filled with Chl2 offsetting Chl1 flakes deformed in a ductile way in mylonite B10-31. (f) Chl + Wm flakes within interconnected layers of white mica in 
mylonite ZA16-133. Cracks filled with Chl2 and deformed quartz (full of fluid inclusions) are also visible. Ant: anatase, Wm: white mica.

Discretely deformed samples exhibit an asymmetric texture (Fig. 2b, e). Little deformed domains of granitoid show petrological features similar to undeformed samples with a weak schistosity (S) defined by Chl1 flakes after biotite and amphibole pseudomorphs (Fig. 2b, e, Fig. 3d). These domains alternate with mmlarge parallel fractures at high angle $\left(\sim 40^{\circ}\right)$ to the $S$ (Fig. 2b, e and 3d) that cross-cut the entire thin section and displace Chl1 flakes (Fig.2b, e). Secondary chlorite (thereafter Chl2) fills the fractures (Fig. 3d, 4e). The boundaries between
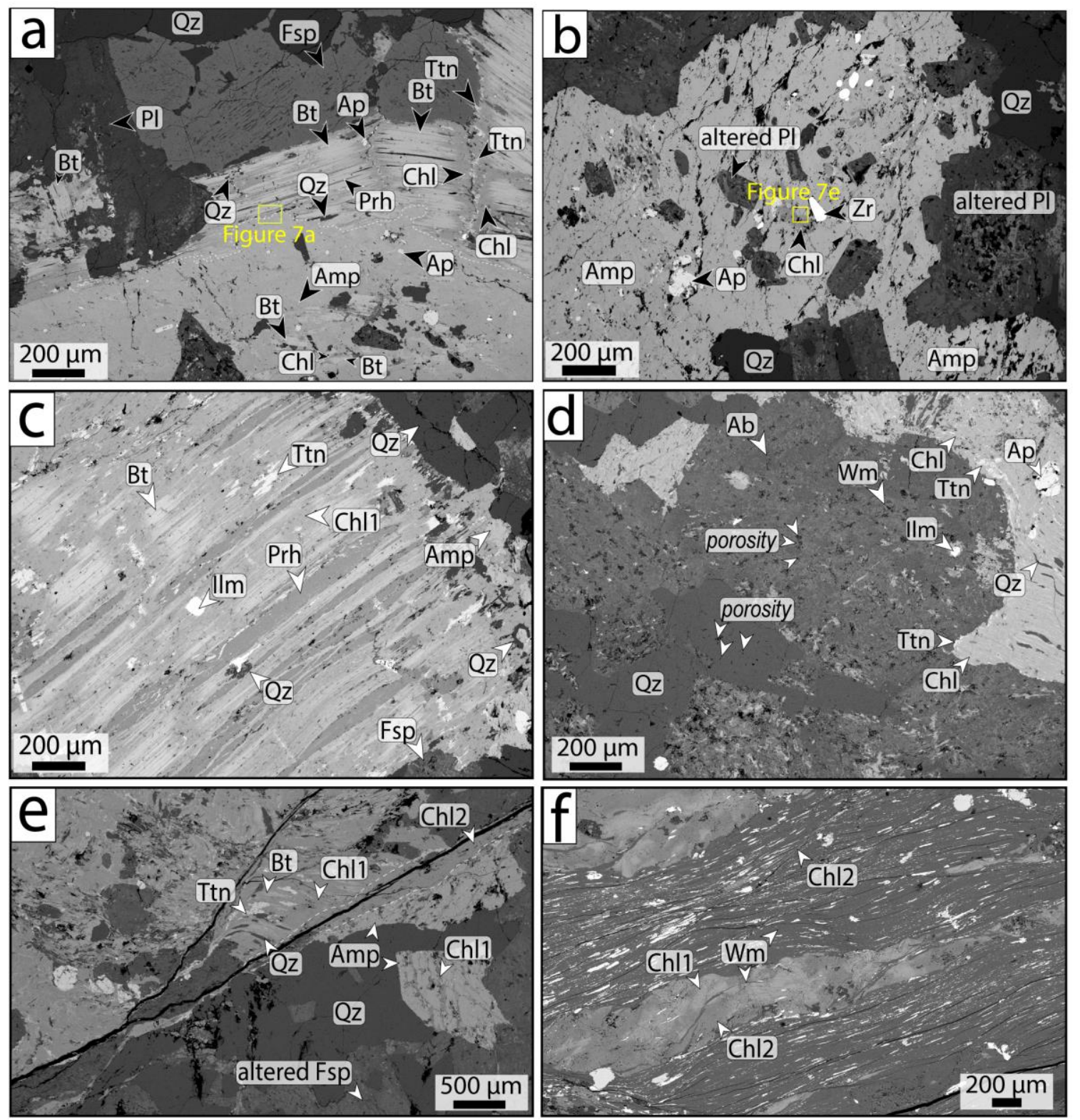

Figure 4 Backscattered electron SEM images. (a) Chloritized amphibole and biotite in undeformed but altered sample ZA16-119. Yellow square: location of the FIB section of Figure 7a. (b) Magmatic amphibole altered to chlorite in undeformed but altered sample ZA16-84. Yellow square: location of the FIB section of Figure 7e. (c) 
Biotite grain in sample ZA16-84 altered to chlorite, prehnite, titanite and quartz (see Fig. 3a for location of the image at lower magnitude). (d) Porosity formation after pseudomorphic replacement of feldspar by white mica + albite in the undeformed sample ZA16-119. (e) Chl2-bearing fractures in discretely deformed samples ZA16-78 (see Fig. $2 \mathrm{~b}$ for location at lower magnitude). (f) Chl2 within Chl1 + Wm boudin, elongated in S (mylonite ZA16133).

In mylonites, interconnected layers of white mica and layers of segmented quartz grains define the schistosity $\mathrm{S}$ (Fig. 2c, f). Flakes of Chl1 \pm white mica are stretched and folded along $\mathrm{S}$ (Fig. 3e, f, 4f). Chl2 crystallises (i) in sinuous cracks, a few $\mathrm{mm}$ long, subparallel to apparent $\mathrm{C}$ planes (Fig. 2f, 3e, 3f, 5c), (ii) in tails of Chl1+white mica flakes and of quartz grains, sub-parallel to $\mathrm{S}$ (Fig. 2f), (iii) in boudins of $\mathrm{Chl} 1+$ white mica flakes after biotite (Fig. 4f, 6h). Other cracks observed in some mylonites (e.g. Fig. 2c) are not filled with $\mathrm{Chl} 2$, but rather with calcite or oxides and are at a different angle to C-S. Feldspars are completely transformed (mainly to white mica, Fig. 4f), relicts of amphibole and biotite are very rarely observed (Fig. 2c, f, 3e, f). Quartz grains are fractured, with fractures at high angle to the foliation and stretched along S (Fig. 2f). They are kinked around fractures and exhibit a stronger irregular extinction than in undeformed samples. Fluid inclusions in quartz are more abundant than in undeformed and discretely deformed samples. They form a dense net of trails giving a dark dusty appearance to the grains (Fig. 2c, f, 3e, f).

\section{COMPOSITIONAL VARIATIONS}

Representative composition maps of mineral assemblages in variably deformed samples are shown in Figures 5 and 6. Biotite has homogeneous composition (Table 1). The interlayer charges below ideal values may be due to $\mathrm{K}$ leaching (e.g. via hydronium substitution). The magmatic amphibole is zoned from magnesiohornblende (core) to actinolite (rims, Table 1).
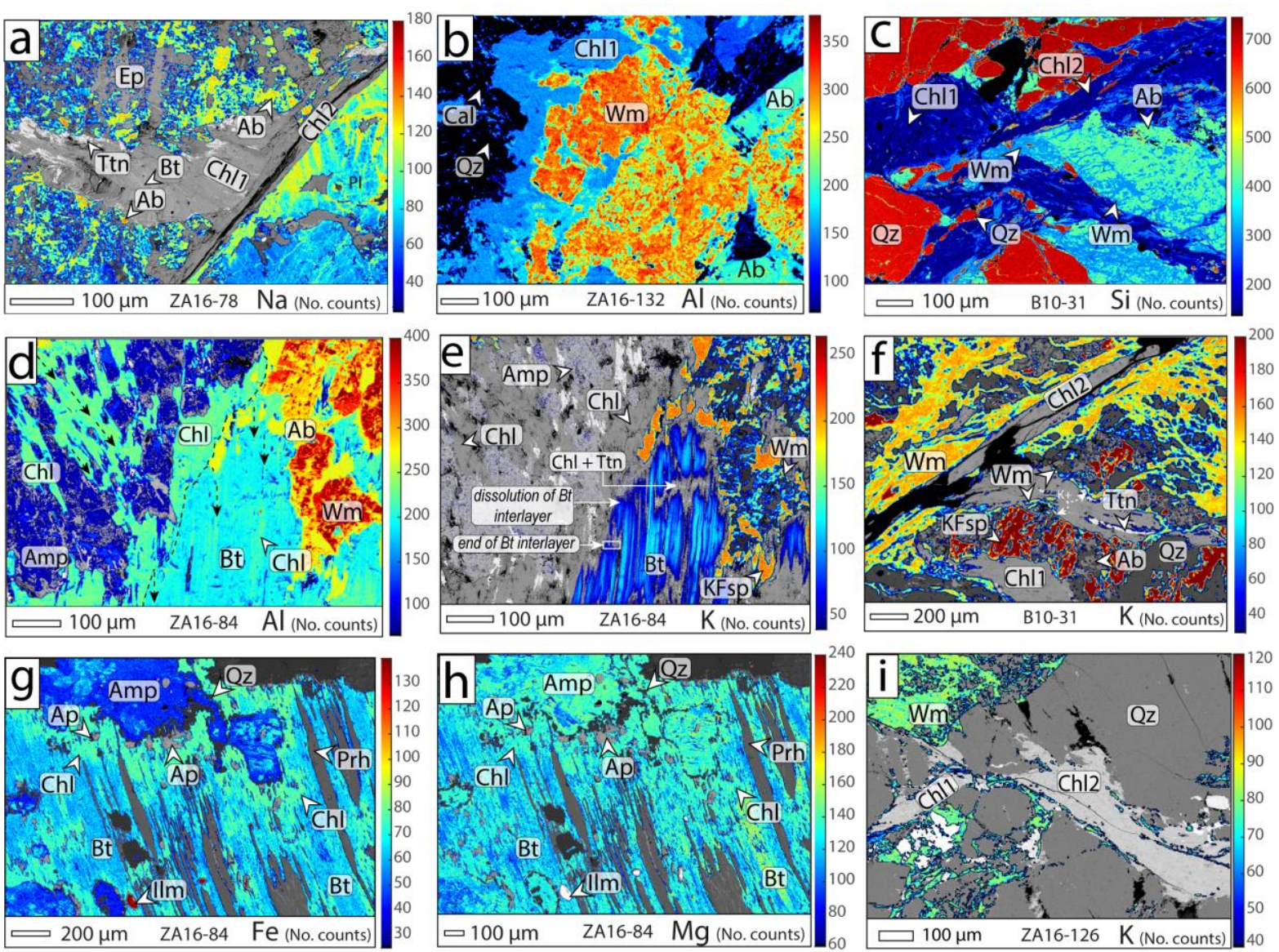

Figure 5 Composition maps (raw data in number of counts) over BSE images. (a) Fracture separating relict of zoned magmatic plagioclase (lower right angle) from altered plagioclase (colored) and chloritized biotite (grey) in 
a discretely deformed sample. (b) Pseudomorphic breakdown of alkali feldspar in a discretely deformed sample. (c) Deformed micrograins of quartz and albite in the net of white mica in a mylonite. (d) and (f) $\mathrm{Al}$ and $\mathrm{K}$ distribution at the boundary between chloritized amphibole, chloritized biotite and albite + white mica pseudomorphs after alkali feldspar in an undeformed sample (grey in amphibole is Al-depleted actinolite). (f) Relicts of K-feldspar and distribution of white mica in the matrix ( $\mathrm{K}$ map). $\left(\mathrm{g}\right.$ ) and (h) $\mathrm{Fe}_{\mathrm{tot}}$ and $\mathrm{Mg}$ maps of chloritized biotite grain in undeformed sample ZA16-84. (i) White mica rimming chlorite flakes (Chl1) in mylonite ZA16-126 (K map). White is iron oxide.

In undeformed samples, relicts of plagioclase preserve the magmatic $\mathrm{Na}-\mathrm{Ca}$ zoning, as in undeformed portions of discretely deformed samples (Fig. 5a). Albite, calcite and rare epidote after plagioclase pseudomorphs (Fig. 5a) as well as albite and white mica after alkali feldspar breakdown (Fig. 5b, c) preserve to some extent the compositional heterogeneities of the parent mineral. Patchy $\mathrm{Fe}$ variations are observed at microscale and coincide with biotite and amphibole breaking down to chlorite (Fig. $5 \mathrm{~d}, \mathrm{~g}$ ). Variations in $\mathrm{Mg}$ content also occur at microscale, uncorrelated to grain boundaries (Fig. 5h). In biotite, the $\mathrm{K}$ content decreases from core to rim along biotite cleavages, due to chloritization (Fig. 5e). $\mathrm{K}$ is localized (i) in white mica associated to chlorite as product of biotite chloritization (e.g. Fig. 6b), (ii) in white mica rimming chlorite flakes (Fig. 5f, i) and (iii) in white mica after feldspar breakdown in matrix (Fig. 5b-f). Chlorite replacing amphibole and biotite at biotiteamphibole boundary has in general slightly higher $\mathrm{Al}\left(\mathrm{Al}_{2} \mathrm{O}_{3} 19-21 \mathrm{wt} \%\right)$ and $\mathrm{Fe}\left(\mathrm{FeO}_{\text {tot }} 24-\right.$ $26 \mathrm{wt} \%$ ) contents than chlorite replacing biotite along cleavages $\left(\mathrm{Al}_{2} \mathrm{O}_{3} 17-18 \mathrm{wt} \%, \mathrm{FeO}_{\text {tot }} 21-\right.$ 22 wt \%, Fig. 5d, 6a; see also Table1 and BSE contrast in Fig. S4d of the Supplementary Material). Thereafter, Chl1a designates the Al- richer chlorite found in amphibole and at biotite-amphibole boundary, Chl1b designates the Al-poorer chlorite in biotite. The Al-richer chlorite (Chl1a) is also locally observed in altered biotite grains (Fig. 6c). Chl1b in biotite grains exhibits patchier zoning than Chlla at the biotite-amphibole rim (Fig. 6a, c) and presents concentric microscale variations of $\mathrm{Al}$ (e.g. $\mathrm{Al}_{2} \mathrm{O}_{3}$ of 18 to 20 wt.\%), Fe and $\mathrm{Mg}$ contents (as in sample ZA16-79: Fig. 6b and Fig. S3d in Supplementary Material).

In discretely deformed samples and in mylonites, two compositional groups of chlorite are observed. Chlorite after biotite and amphibole pseudomorphs (Chl1) shares similar characteristics with Chl1 (Chlla and Chl1b according to the microstructural position) of undeformed samples, being more heterogeneous at microscale, Fe-richer (24-26 wt.\% of $\mathrm{FeO}_{\text {tot }}$ ) and Al-poorer (18-20 wt.\% $\mathrm{Al}_{2} \mathrm{O}_{3}$ ) than chlorite filling fractures. This last chlorite is defined as $\mathrm{Chl} 2$ (17-18 wt.\% $\mathrm{FeO}_{\text {tot }}$, 21-22 wt $\% \mathrm{Al}_{2} \mathrm{O}_{3}$, Fig. 6d, e, Fig. S1b and Table $1)$. The sharp composition boundary between Chl1 and Chl2 attests of little element transfer and lack of re-equilibration across fractures (Fig. 6d, e).

Table 1. Representative composition of amphibole, biotite and chlorite. All iron is reported as FeO

\begin{tabular}{|c|c|c|c|c|c|c|c|c|c|c|c|c|c|c|c|c|c|c|c|c|}
\hline \multirow{3}{*}{$\begin{array}{c}\text { Sample } \\
\begin{array}{c}\text { LatlLong } \\
\text { Deformation }\end{array} \\
\text { Mineral } \\
\end{array}$} & \multicolumn{4}{|c|}{ ZA16-84 } & \multirow{2}{*}{\multicolumn{4}{|c|}{$\begin{array}{c}\text { ZA16-119 } \\
2^{\circ} 3946.4^{*} \mathrm{~N} 0^{\circ} 16^{1} 143^{\circ} \mathrm{E} \\
\text { Undeformed }\end{array}$}} & \multirow{2}{*}{\multicolumn{2}{|c|}{\begin{tabular}{|c|} 
ZA16-79 \\
$42^{\circ} 3958.9^{\prime} \mathrm{N} 0^{\circ} 178.95^{\circ} \mathrm{E}$
\end{tabular}}} & \multirow{2}{*}{\multicolumn{2}{|c|}{$\frac{\text { ZA16-82 }}{42^{\circ} 4073^{\circ} \mathrm{N} 0^{\circ} 16^{\circ} 43.3^{\prime \prime}}$}} & \multicolumn{2}{|c|}{ ZA16-78 } & \multicolumn{2}{|c|}{ ZA16-133 } & \multicolumn{2}{|c|}{$B 10-31$} & \multirow{2}{*}{\multicolumn{2}{|c|}{$\begin{array}{c}\text { ZA16-126 } \\
42^{\circ} 39489^{\circ} \mathrm{NN} 0^{\circ} 16^{1} 175^{\circ} \mathrm{E} \\
\text { Mylonite }\end{array}$}} \\
\hline & \multicolumn{4}{|c|}{$\begin{array}{c}42^{\circ} 4073^{\circ} \mathrm{N} 0^{\circ} 16^{\circ} 43.3^{\circ} \mathrm{E} \\
\text { Undeformed }\end{array}$} & & & & & & & & & \multicolumn{2}{|c|}{$\begin{array}{c}42^{\circ} 3959.44^{\mathrm{N}} \mathrm{N}^{\circ} 178.5^{\circ} \mathrm{E} \\
\text { Discretely deformed }\end{array}$} & \multicolumn{2}{|c|}{$\begin{array}{c}2^{\circ} 3949.5^{\circ} \mathrm{N}^{\circ}{ }^{\circ} 16^{6} 17.8^{\circ} \\
\text { Mylonite }\end{array}$} & \multicolumn{2}{|c|}{$\begin{array}{l}42^{\circ} 3949.2^{\circ} \mathrm{N} 0^{\circ} 1744^{\circ} \mathrm{E} \\
\text { Mylonite }\end{array}$} & & \\
\hline & Amphl & $\begin{array}{l}\text { Bt } \\
\text { t }\end{array}$ & Chlia & Chlib & Amphl & Bt & Chl1a & Chlib & Chl1 & Chl1 & Chl1 & Chl2 & Chl1 & Chl2 & Chl1 & Chl2 & Chl1 & Chl2 & Chl1 & Chl2 \\
\hline \multicolumn{21}{|l|}{ Oxides } \\
\hline $\mathrm{SiO} 2$ & 48.35 & 36.68 & 27.32 & 29.59 & 50.92 & 36.83 & 27.46 & 27.68 & 27.04 & 26.72 & 27.60 & 28.37 & 27.30 & 28.82 & 26.33 & 27.03 & 27.37 & 26.78 & 26.02 & 28.67 \\
\hline $\mathrm{TiO} 2$ & 1.22 & 3.10 & 0.02 & 1.56 & 0.32 & 271 & 0.13 & 0.18 & 0.01 & 0.21 & 0.07 & 0.05 & 0.66 & 0.01 & 0.05 & 0.19 & 0.24 & 0.01 & $<D L$ & 0.04 \\
\hline Al2O3 & 6.88 & 15.29 & 19.71 & 17.68 & 4.53 & 13.98 & 18.60 & 17.45 & 20.20 & 18.81 & 1981 & 20.57 & 18.72 & 19.41 & 23.11 & 21.38 & 19.12 & 2267 & 21.20 & 23.86 \\
\hline $\mathrm{FeO}$ & 16.91 & 19.38 & 25.74 & 2298 & 18.49 & 22.40 & 28.38 & 27.88 & 25.81 & 23.93 & 23.85 & 1785 & 24.66 & 23.34 & 2622 & 22.15 & 26.67 & 28.07 & 29.50 & 25.93 \\
\hline MnO & 0.29 & 0.21 & 0.36 & 0.32 & 0.71 & 0.36 & 0.47 & 0.39 & 0.30 & 0.31 & 0.52 & 0.43 & 0.38 & 0.41 & 0.15 & 0.12 & 0.42 & 0.53 & 0.42 & 0.31 \\
\hline $\mathrm{MgO}$ & 12.69 & 1215 & 15.41 & 15.79 & 12.04 & 10.60 & 13.54 & 13.91 & 14.64 & 15.97 & 16.28 & 2026 & 14.99 & 16.03 & 13.17 & 17.05 & 14.42 & 10.86 & 11.88 & 8.86 \\
\hline $\mathrm{CaO}$ & 10.64 & 0.03 & 0.06 & 0.53 & 10.61 & 0.05 & 0.07 & 0.22 & 0.05 & 0.04 & 0.09 & 0.10 & 0.48 & 0.13 & 0.04 & 0.10 & 0.03 & 0.05 & 0.07 & 0.11 \\
\hline $\mathrm{Na} 2 \mathrm{O}$ & 1.17 & 0.10 & 0.00 & $<D L$ & 0.77 & 0.07 & $\angle D L$ & 0.02 & 0.04 & 0.04 & 0.07 & 0.02 & 0.02 & 0.05 & 0.05 & 0.07 & $\angle D L$. & 0.02 & 0.02 & 0.03 \\
\hline $\mathrm{K} 2 \mathrm{O}$ & 0.48 & 7.90 & 0.02 & 0.33 & 0.36 & 9.20 & 0.01 & 0.17 & 0.05 & 0.02 & 0.08 & 0.02 & 0.16 & 0.02 & 0.02 & 0.04 & 0.02 & 0.10 & $\angle D L$ & 1.80 \\
\hline Total & 98.15 & > 86.94 & ${ }^{\prime} 88.62$ & 88.86 & 98.76 & 96.20 & 88.65 & 87.90 & 88.14 & 86.09 & 88.38 & 87.67 & 87.37 & 88.21 & 89.15 & 88.13 & 8830 & 89.10 & 89.12 & 89.63 \\
\hline \multicolumn{21}{|c|}{ 50.15 $00.54 \quad 00.02$} \\
\hline $\mathrm{Si}$ & 709 & 279 & 279 & 298 & 7.47 & 283 & 2.90 & 295 & 283 & 281 & 281 & 282 & 282 & 2.86 & 268 & 258 & 283 & 277 & 275 & 2.95 \\
\hline $\mathrm{Ti}$ & 0.13 & 0.18 & 0.00 & 0.12 & 0.04 & 0.16 & 0.01 & 0.01 & 0.00 & 0.02 & 0.01 & 0.03 & 0.05 & 0.00 & 0.00 & 0.03 & 0.02 & 0.00 & 0.00 & 0.00 \\
\hline Al & 1.19 & 1.37 & 237 & 210 & 0.78 & 1.27 & 232 & 220 & 249 & 2.33 & 238 & 233 & 228 & 2.37 & 263 & 251 & 2.33 & 277 & 264 & 290 \\
\hline FеTOT & 2.07 & 123 & 2.12 & 1.87 & 2.27 & 1.44 & 251 & 249 & 226 & 204 & 1.97 & 1.52 & 205 & 1.93 & 1.93 & 206 & 224 & 240 & 261 & 2.23 \\
\hline $\mathrm{Mn}$ & 0.04 & 0.01 & 0.03 & 0.03 & 0.09 & 0.02 & 0.04 & 0.04 & 0.03 & 0.03 & 0.05 & 0.03 & 0.03 & 0.03 & 0.01 & 0.01 & 0.04 & 0.05 & 0.04 & 0.03 \\
\hline $\mathrm{Mg}$ & 277 & 1.38 & 2.35 & 237 & 2.63 & 121 & 213 & 221 & 229 & 250 & 247 & 2.85 & 231 & 238 & 257 & 253 & 222 & 1.68 & 1.87 & 1.36 \\
\hline $\mathrm{Ca}$ & 1.67 & 0.00 & 0.01 & 0.06 & 1.67 & 0.00 & 0.01 & 0.03 & 0.01 & 0.00 & 0.01 & 0.04 & 0.05 & 0.02 & 0.01 & 0.01 & 0.00 & 0.01 & 0.01 & 0.01 \\
\hline $\mathrm{Na}$ & 0.33 & 0.01 & 0.00 & 0.00 & 0.22 & 0.01 & 0.00 & 0.00 & 0.01 & 0.01 & 0.01 & 0.01 & 0.00 & 0.01 & 0.00 & 0.00 & -0.01 & 0.00 & 0.00 & 0.01 \\
\hline K & 0.09 & 0.77 & 0.00 & 0.04 & 0.07 & 0.90 & 0.00 & 0.02 & 0.01 & 0.00 & 0.01 & 0.00 & 0.02 & 0.01 & 0.00 & 0.01 & 0.00 & 0.01 & 0.00 & 0.24 \\
\hline Oxygens & 23 & 11 & 14 & 14 & 23 & 11 & 14 & 14 & 14 & 14 & 14 & 14 & 14 & 14 & 14 & 14 & 14 & 14 & 14 & 14 \\
\hline XMg & 0.57 & 0.53 & 0.53 & 0.56 & 0.54 & 0.46 & 0.46 & 0.47 & 0.50 & 0.63 & 0.63 & 0.78 & 0.53 & 0.55 & 0.62 & 0.66 & 0.58 & 0.45 & 0.42 & 0.38 \\
\hline$A M I$ & 0.28 & 0.33 & 1.17 & 1.20 & 0.26 & 0.25 & 1.23 & 1.16 & 1.33 & 1.15 & 1.20 & 1.18 & 1.15 & 1.23 & 1.31 & 1.13 & 1.18 & 1.54 & 1.40 & 1.85 \\
\hline Octahedral sum & 5.16 & 2.96 & 5.67 & 5.47 & 5.25 & 2.92 & 5.92 & 590 & 5.74 & 5.72 & 5.69 & 5.58 & 5.46 & 5.59 & 5.82 & 5.73 & 5.67 & 5.66 & 5.92 & 5.47 \\
\hline
\end{tabular}


In mylonites, composition maps show that $\mathrm{Chl} 2$ grew along and around cracks (Fig. 6f, $\mathrm{g}, \mathrm{i})$ and within Chl1 flakes (Fig. 6h and Fig. S3a, b) to a distance of 200-300 $\mu \mathrm{m}$ from cracks, suggesting partial replacement of Chl1 by Chl2. In discretely deformed samples and mylonites, the amount of $\mathrm{Chl} 2$ is higher than that of Chl1 in fractures and microcracks, and lower in the matrix (Fig. S1a), although the amount of $\mathrm{Chl} 2$ increases from undeformed samples - where only Chl1 is observed - to mylonites (Fig. S1a). Hence, while Chl1 is dominant over $\mathrm{Chl} 2$ in the matrix of the granitoid (outside microcracks), the growth of $\mathrm{Chl} 2$ and the replacement of $\mathrm{Chl} 1$ by $\mathrm{Chl} 2$ appears associated to deformation (fracturing and shearing) and limited to hundreds of microns away from microcracks.
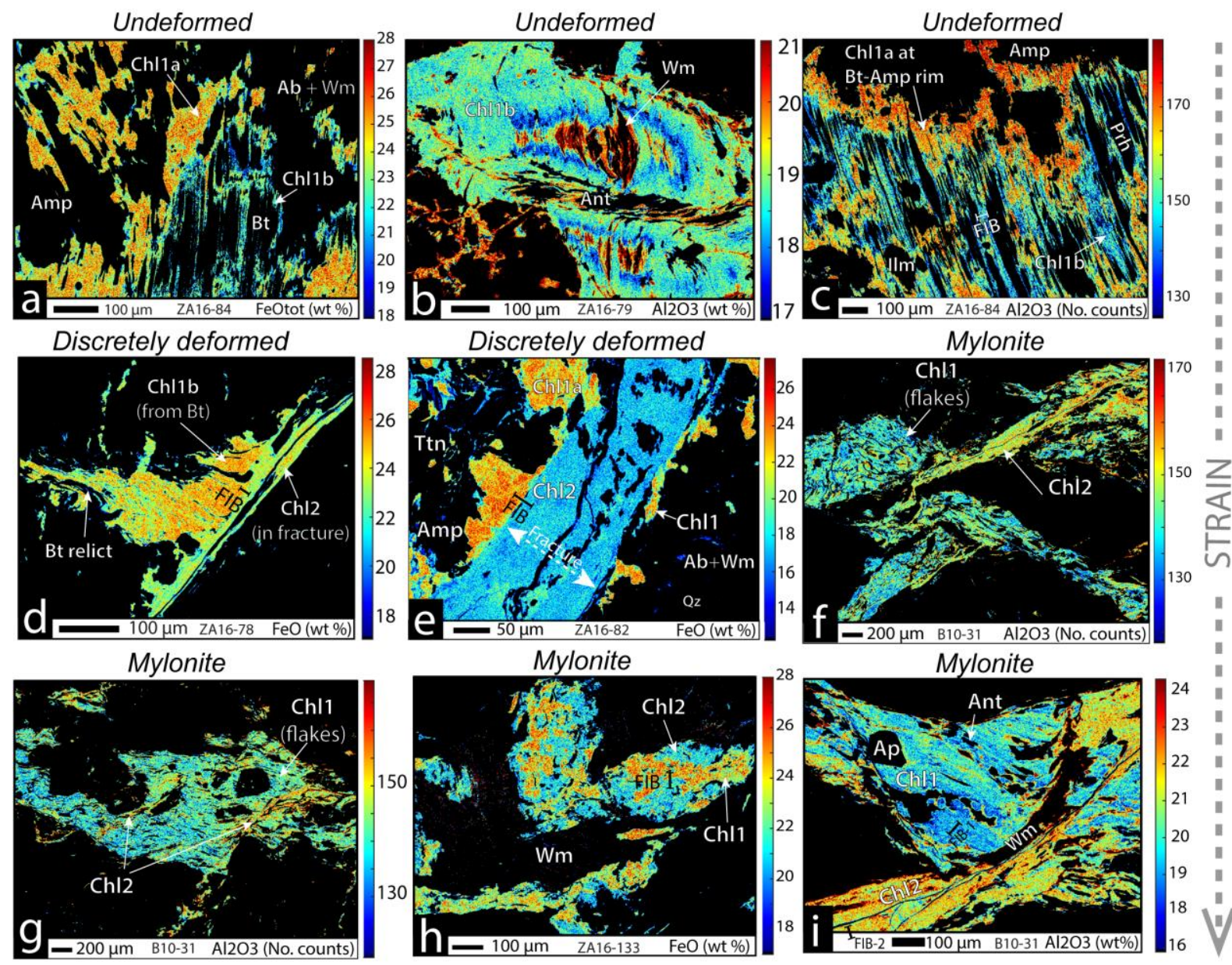

Figure 6 Composition maps of chlorite with increasing strain in wt \% (panels a, b, d, e, h, i) and in number of counts (panels c, f, g). The location of panel a is the same as Figure 5d, e, that of panel c corresponds to Figure 5 $\mathrm{g}, \mathrm{h}$ and panel $\mathrm{d}$ to Figure 5a. The location of the FIB sections is reported for panels $\mathrm{d}, \mathrm{e}, \mathrm{h}$ and $\mathrm{i}$.

\section{NANOSTRUCTURES}

Ten FIB foils were cut into thin sections at the boundary between biotite and Chl1a, amphibole and Chl1a, in chloritized biotite grains and at the boundary between in Chl1 and Chl2 in deformed samples. This allows nanostructures of chloritization reactions to be associated to the micrometric compositional heterogeneities observed in composition maps.

\subsection{Amphibole to chlorite reaction}

In FIB foils cut in undeformed samples ZA16119 (Fig. 7a) and ZA16-84 (Fig. 7e), atomic arrangement is clearly observed in Chl1a but hardly seen in amphibole (Fig. 7b, c and f). The interface between the two minerals is sharp and underlined by a contrast change in bright field STEM imaging (Fig. 7b, $c$ and f). In sample ZA16-119, the Chl1a-amphibole interface is much thinner $(<20 \mathrm{~nm})$ than in sample ZA16- 
$84(\sim 100 \quad \mathrm{~nm})$, with chlorite sheets progressively intruding amphibole (Fig. 7c) or separated from amphibole by a low electron density area (Fig. 7b). In packets of Chlla sheets, triangular defects with higher refraction contrast than chlorite sheets are observed. Such defects may correspond to the low angle grain boundaries (LAGB, Fig. 7c and Fig. S2c) described by Kogure and Murakami (1998). In chlorite, "en echelon" pores are also observed and tend to merge in a single fracture (Fig. 7b and inset). Chlorite at the amphibole interface is bended, as shown by high angle limits observed in crystallites and variable refraction of chlorite sheets (inset in Fig. 7b, c). In sample ZA16-84, at the Chl1a-amphibole interface, chlorite sheets split to form lenticular pores opening perpendicular to the $c$ axis of chlorite (inset of Fig. 7f). Pores reach $80 \mathrm{~nm}$ long and 6-20 nm thick. Such pores are not observed in chlorite crystallites or in unaltered amphibole. The chlorite-amphibole (Amp I) interface is also marked by the presence of a thin $\operatorname{rim}(<100 \mathrm{~nm}$ in width) penetrating amphibole (Fig. 7f, g), identified as another amphibole from the local Fourier transform of STEM diffraction image (Amp II in Fig. 7f, see also Fig. S2a, b).
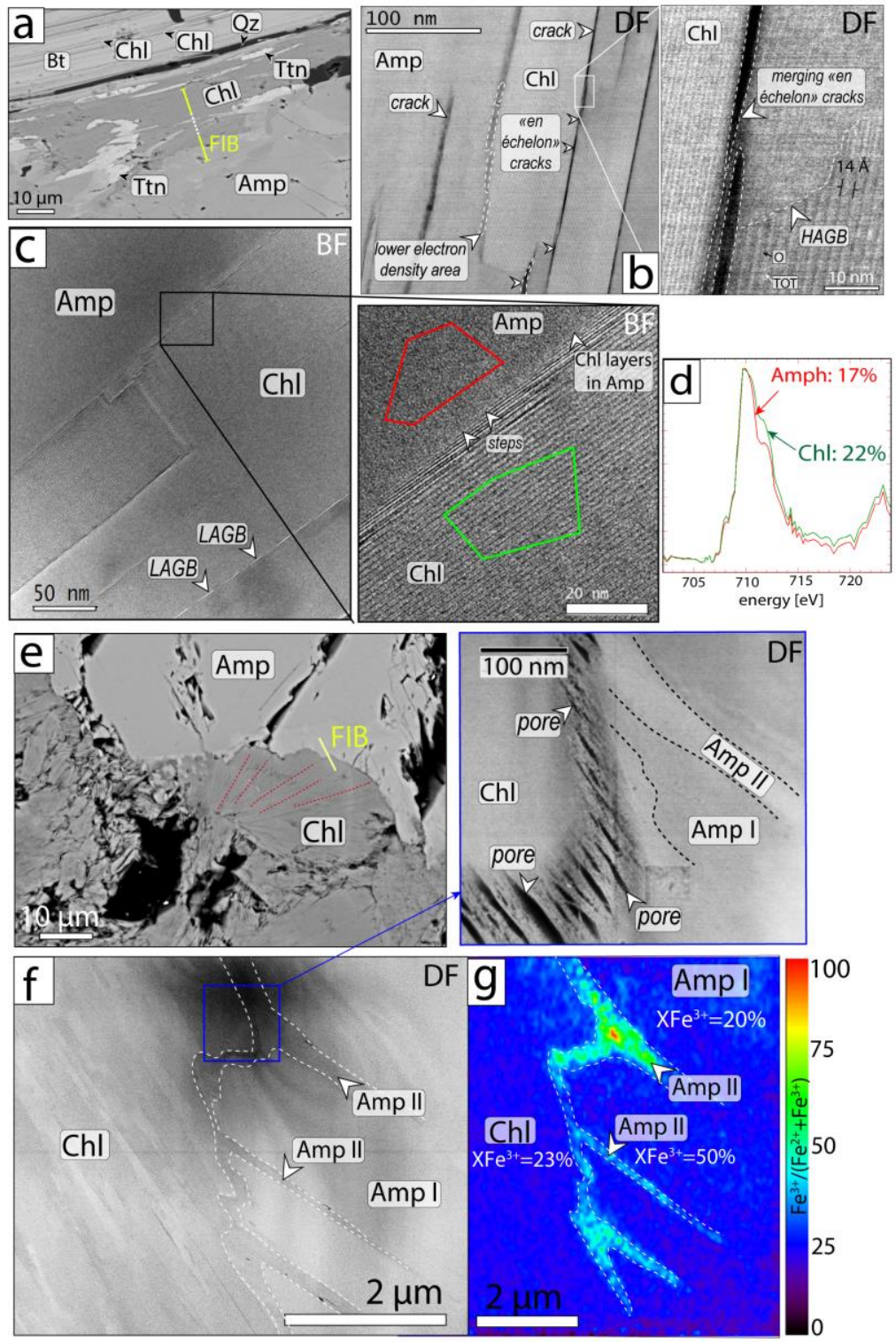

Figure 7 BSE, TEM images and $\mathrm{XFe}^{3+}$ estimates for chloritized amphibole in undeformed sample ZA16-119 (ad) and ZA16-84 (e-g). (a) Location of FIB section over BSE image of sample ZA16-119. A less magnified view is provided in Figure 4a. (b) TEM dark-field image of amphibole-chlorite boundary in FIB section of sample ZA16-119. (c) Close-up view of amphibole-chlorite boundary (FIB section). (d) Raw STXM iron spectra for areas in panel c, and estimated $\mathrm{XFe}^{3+}(\%)$. (e) BSE image and location of the FIB section at the amphibole-chlorite 
boundary in sample ZA16-84. (f) STEM image (and enlarged view) of the chlorite-amphibole boundary in FIB section of sample ZA1-84. Black dotted lines underlines Amph II boundaries. (g) STXM XFe ${ }^{3+}(\%)$ map corresponding to panel $f$ of the chlorite-amphibole boundary. HAGB: high angle grain boundary. LAGB: low angle grain boundary. DF: Dark field, BF: bright field.

\subsection{Chloritization of biotite}

In the undeformed granodiorites ZA16-84 and ZA16-119, FIB foils were also cut in chloritized biotite grains (Fig. 8) and at rims of chloritized biotite (Fig. 9). STEM images show that areas of unaltered biotite are constituted of regularly alternating tetrahedral and octahedral sheets (TOT) and interlayers (A sites), locally alternating with chlorite (TOT-O) (left side in Fig. 8b and Fig. 9c). In places, biotite grains exhibit intra-crystalline defects with interlayer widening and an increase of the $c$ axis from $\sim 10$ $\AA$ to $\sim 20 \AA$ (bright space in Fig. 9d due to lower electron density). These lenticular defects are sparse and poorly interconnected, at least in 2D, but they merge locally in larger nanocracks (white arrow in Fig. 9c) or coalesce as ripple cavities (orange in Fig. 9c). In areas where biotite breaks down to chlorite, two types of biotite-chlorite interface are observed. The first type consists of a thin biotite-chlorite (Chllb) interlayering at the scale of tens of nanometers included in biotite grains (Fig. 8a, b right side of Fig. 9b, Fig. 9g, f). The second type of biotite-chlorite interface corresponds to a sharp boundary between Chlla and biotite (Fig. 9a, left side of Fig. 9b, Fig. 9h, i).
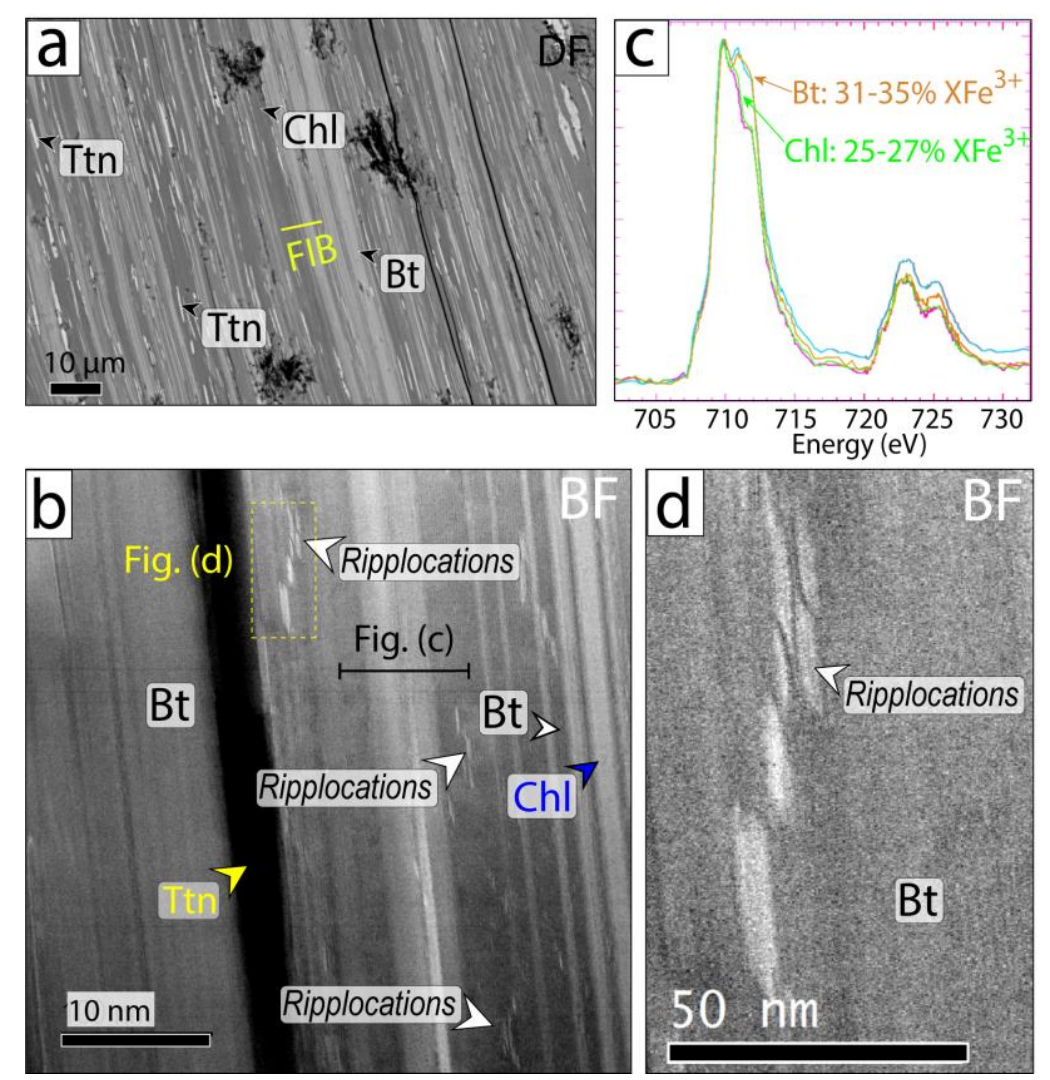

Figure 8 BSE, STEM images and $\mathrm{XFe}^{3+}(\%)$ in chloritized biotite in sample ZA16-84. (a) BSE image of biotite chloritized layer-by-layer and location of the FIB foil of panel b. (b) TEM image of chlorite and biotite crystallites in FIB foil. Ripplocations are visible in biotite only. (c) Raw STXM iron spectra and $\mathrm{XFe}^{3+}$ estimates for chlorite and biotite. (d)

Zoomed view of panel (b) showing ripplocation-like defects (FIB foil). BF: bright field, DF: dark field.

The first type of chlorite-biotite interface is well observed in sample ZA16-84, where biotite sheets of 5-10 nm are interlayered with Chl1b domains 10-50 nm large, with 30$40 \mathrm{~nm}$ titanite needles and silica nanoprecipitates (Fig. 8a, b). In sample ZA16-
119 , pristine biotite is locally interlayered with Chllb (Fig. 9b, c) and with a succession of biotite and chlorite layers identified as corrensite-like sheets (Shau et al. 1990; Fig. 9g). Chl1b interlayered with biotite exhibits a similar orientation to biotite (same axial zone in 
STEM, Fig. 8b, 9b) and grows by two mechanisms: (1) insertion of a brucitic layer (light grey level) in the former biotite interlayer and (2) dissolution of two tetrahedral layers of biotite to form chlorite (Fig. 9f, i), as described by Veblen and Ferry (1983) and Yuguchi et al. (2015). Both mechanisms translate at microscale as isolated packets of chlorite 1-2 $\mu \mathrm{m}$ large in biotite. Areas with high density of alternating corrensite-like sheets and chlorite at nanoscale show thin, vanishing $\mathrm{K}$-rich layers at microscale (e.g. as in Fig. 6a). In the vicinity of chloritized biotite layers, biotite deforms by A site opening and sheet bending (Fig. 9f). Widening of interlayer spaces is characterized by lowering of the interlayer electron density and cohesion, and may evolve into pores (Fig. $8 b$, d and Fig. 9b, h). Such intra-crystalline defects are observed only in biotite sheets and share the characteristics of the ripplocations described by Aslin et al. (2019). Ripplocations are arranged in ripples aligned along two axes at $\sim 30^{\circ}$ (Fig. 8 b, d, $9 \mathrm{~h}$ ) and oriented in the same plane since they disappear simultaneously under the TEM when tilting the sample.
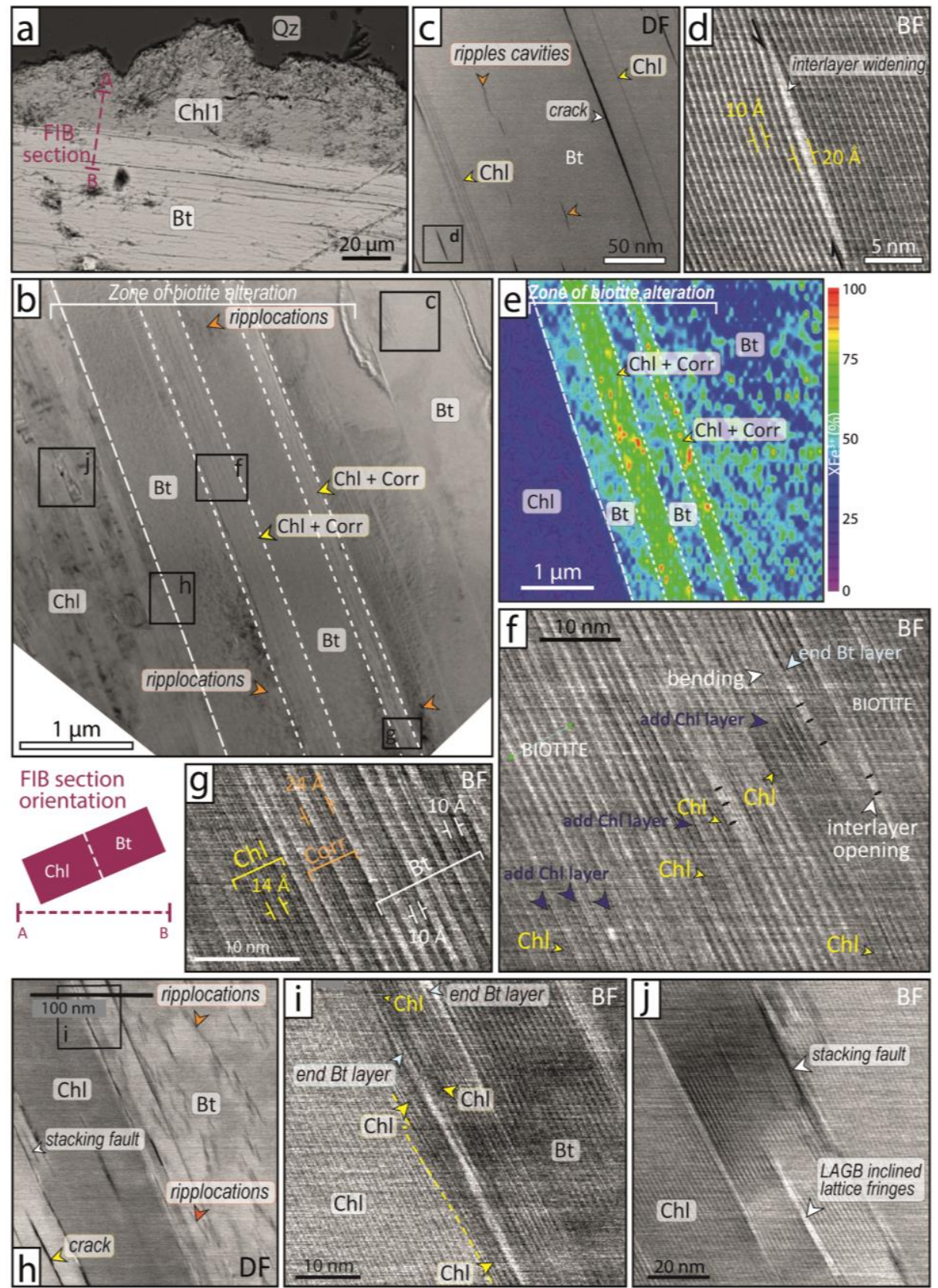

Figure 9 BSE, STEM images and $\mathrm{XFe}^{3+}(\%)$ in chloritized biotite in sample ZA16-119. (a) Location of the FIB foil at the biotite-chlorite rim in a BSE image. (b) Low magnification STEM image of the central part of the FIB 
foil showing two types of biotite-chlorite rims: sharp and interlayered (see the sketch of FIB section orientation). (c) STEM view of pristine biotite in FIB foil (zoomed view of panel b). (d) Close-up view of defects in pristine biotite. (e) $\mathrm{XFe}^{3+}(\%)$ STXM map of the entire panel b. (f) Mechanisms of biotite layer-by-layer chloritization (see panel $\mathrm{b}$ for location). (g) Chlorite alternates with corrensite-like sheets in altered biotite (see panel $\mathrm{b}$ for location). (h) Ripplocations-like structures in biotite close to chlorite-biotite interface (see panel b for location). (i) Close-up view of the sharp interface between chlorite and biotite (see panel h for location). (j) Nanofeatures in chlorite with a sharp boundary with biotite (Chlla, see panel b for location). DF: dark field, BF: bright field.

The second type of chlorite-biotite boundary (Chlla in sharp contact with biotite) is mainly recognized in sample ZA16-119 at nanoscale (left side in Fig. 9b) and ZA16-84 at microscale (e.g. Fig. 6c). The chlorite-biotite interface is in this case coherent (continuous structures across the interface, Fig. 9h, i) but chlorite has a very different orientation from biotite (different axial zone coordinates in STEM) and does not show intra-grain defects associated to layer bending (Fig. 9b, i). This suggests epitaxial growth of Chlla over a biotite already internally deformed at nanoscale. This biotite-chlorite interface is located $\sim 1 \mu \mathrm{m}$ away from the areas where Chllb and corrensite-like layers replace biotite (Fig. 9b).

In Chl1a, lenticular pores are found at the rims of crystallites and locally merge into cracks (Fig. 9h, j). Other defects are visible as changes in the orientation of chlorite sheets (5$6^{\circ}$ ) and staking faults, with a sharp contrast in refraction (Fig. 9h, j). Triangular defects initiate or terminate in chlorite grains and appear white in bright field images (e.g. Fig. 9j), with lower electronic density interpreted as absence of brucitic layer, as for the LAGB identified in chlorite replacing amphibole (Fig. 7c and Fig. $\mathrm{S} 2 \mathrm{c}$ ).

\subsection{Neo-crystallization and replacement of chlorite}

In discretely deformed samples ZA16-82 and ZA16-78, FIB foils were cut at the interface between $\mathrm{Chl} 1$ in flakes and Chl2 filling fractures (Fig. 10a, g). It appears that Chl1 and Chl2 have different nanoscale textures, at microscale differences in composition prevail.

Chl1 (Chl1a in ZA16-82 within amphibole relicts and Chl1b in ZA16-78 within biotite relicts) is found as regular crystallites $\sim 40 \mathrm{~nm}$ large associated to micro and nanoprecipitates and oriented at high angle to fracture walls (Fig. 10b, h). Chl2 does not contain nanoprecipitates, it is more porous (Fig. $10 \mathrm{~b}, \mathrm{~h}$ ) and crystallites are oriented parallel to fracture walls. A moire is observed around the Chl1-Chl2 interface in sample ZA16-82 (Fig. 10h), showing that two differently oriented crystal structures are overlaid. The orientation difference between $\mathrm{Chl} 1$ and $\mathrm{Chl} 2$ sheets suggests high angle grain boundaries $\left(>6^{\circ}\right)$. The wavelength of the moire indicates that both Chl1 and Chl2 are deformed. Defects, pores and stacking faults are all located along the boundaries of chlorite crystallites, forming an interconnected net of partially opened nano- (10 to $100 \mathrm{~nm}$ large) and microcracks (Fig. 10b, h). These cracks also mark the interface between Chl1 and Chl2 (Fig. 10b, h). This interface is sharp, as also observed in SEM images (Fig. 10a, g) and composition maps (Fig. 6d, e).

In mylonites, FIB sections were cut (1) through chlorite flakes showing a patchy composition with both Chl1 and Chl2 (centre of Fig. 11a for B10-31-1, Fig. S3a for ZA16-133), and (2) through Chl2 along and around heterogeneous microscale cracks linked to flakes (bottom-left in Fig. 11a). In chlorite flakes, moirés are observed in the entire FIB section (e.g. inset 1 in Fig. 11b) - not only at the Chl2-filled crack interface as in discretely deformed samples. Only some crystallites exhibit nanoprecipitates (Fig. 11b, bottom right). Many chlorite crystallites are truncated (Fig. 11b). The truncated borders are lobate and rimmed by nanopores (inset 1 in Fig. 11b). A high density of LAGB (inset 2 of Fig. 11b) and partially opened nanocracks (Fig. 11b) is noted among packets of chlorite sheets. These crystallites and areas of high density of defects correspond at microscale to chlorite of mixed Chl1 and Chl2 composition (Fig. 6h, i, see also Fig. S3). In Chl2, crystallites exhibit variable misorientation (angle changes of 6-10 ${ }^{\circ}$, Fig. $11 \mathrm{c}, \mathrm{d}$ ), intra-grain strain (variable contrast within one single crystallite in STEM image of Fig. 11c) and periodic lenticular cavities as etch pits at their rims (Fig. 11d). LAGB are observed between crystallites which may be bent to form nanokinks (Fig. 11d). 

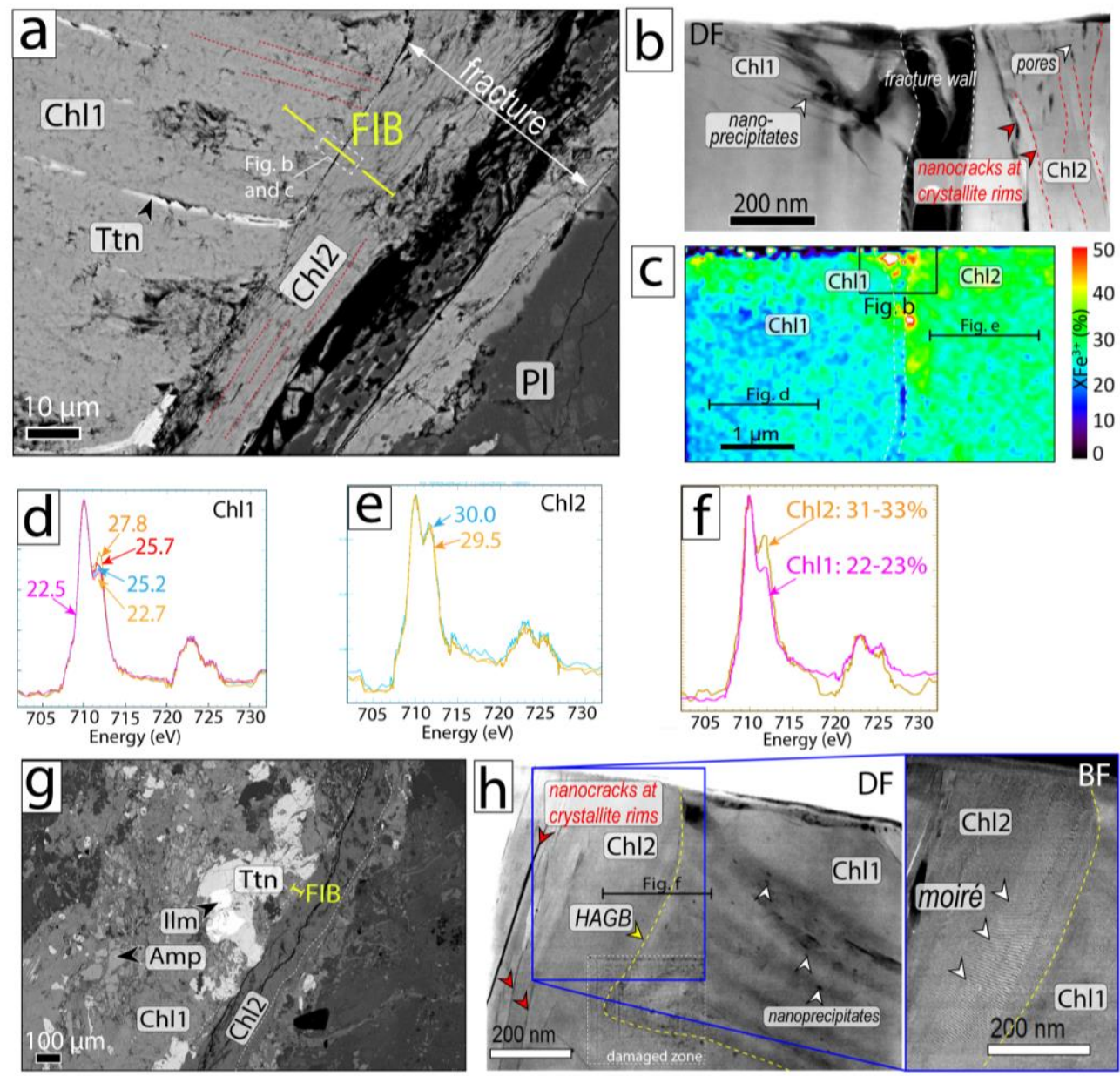

Figure 10 BSE, STEM images and $\mathrm{XFe}^{3+}(\%)$ estimates in chlorite of discretely deformed samples. Y-axis of spectra is relative intensity. (a) Location of the FIB foil in sample ZA16-78 on the BSE image (lower magnification view in the composition map of Figure 6d). Red dotted lines show the orientation of chlorite sheets. (b) STEM image of the FIB foil centred over the boundary between Chl1 and Chl2 marked by the opened fracture wall (white dotted line) seen in panel a. Red: orientation of Chl2 sheets. (c) $\mathrm{XFe}^{3+}(\%)$ map of the Chl1-Chl2 boundary. (d) and (e) Iron STXM spectra for multiple pixels along one transect in Chl1 and one in Chl2 respectively (see panel c for location) and estimated $\mathrm{XFe}^{3+}$. (f) Raw iron spectra in Chl1 and $\mathrm{Chl} 2$ and measured $\mathrm{XFe}^{3+}$ ratio in sample ZA16-82 (see panel $\mathrm{h}$ for the transect location). (g) Location of the FIB foil at the boundary between Chl1 and Chl2 in a BSE image of sample ZA16-82 (enlarged view in the composition map of Figure 6e). (h) Relationships between Chl1 and Chl2 in FIB section with moiré (zoomed frame). Yellow dotted line: boundary between Chl1 and Chl2. DF: dark field, BF: bright field.

\subsection{Spatial distribution of $\mathrm{Fe}^{3+}$ in biotite, amphibole and chlorite}

$\mathrm{XFe}^{3+}$ estimated in chlorite and biotite using STXM-XANES and STEM-EELS with the spectral calibration of Bourdelle et al. (2013) provide similar results within uncertainties (Table 2) for $\mathrm{XFe}^{3+}<25 \%$. Above $25 \%, \mathrm{XFe}^{3+}$ ratios estimated by EELS are on average $2 \%$ lower than ratios obtained by STXM. This is likely due to the energy correction applied to EELS data, not ideal for high $\mathrm{XFe}^{3+}$ (see section 4). Higher spatial and spectral resolutions were achieved with STXM due to beam damaging with STEM, so that STXM values are preferred thereafter.

In sample ZA16-119 and ZA16-84, $\mathrm{XFe}^{3+}$ in amphibole is slightly lower $(\sim 17-20$ $\%)$ than in Chl1a ( 20-23\%, Fig. 7d, g). In ZA16-84, the secondary amphibole (Amph II) at the interface between the first amphibole (Amph I) and Chlla has higher $\mathrm{XFe}^{3+}(\sim 43-$ $50 \%$, Fig. $7 \mathrm{~g}$ and Table 2). The $\mathrm{XFe}^{3+}$ ratio of Chlla is homogeneous at microscale. Biotite crystallites interlayered with $\mathrm{Chl} 1 \mathrm{~b}$ in sample ZA16-84 exhibit a different $\mathrm{XFe}^{3+}(\sim 31-35 \%)$ from Chl1b ( 25\%, Fig. 8c). In sample ZA16- 
119 , biotite exhibits a $\mathrm{XFe}^{3+}$ ratio of $\sim 31 \%$ (Fig. 9e, Table 2), similar to biotite of sample ZA1684. $\mathrm{XFe}^{3+}$ ratios increase up to $70 \%$ in corrensite-like sheets and $\mathrm{XFe}^{3+}$ ratios of 50$60 \%$ are observed in areas containing ripplocations in biotite (Fig. 9b, e). Chlorite shows on average lower $\mathrm{XFe}^{3+}$ than biotite and corrensite-like sheets, with variations linked to the microstructural position: $\mathrm{Chl} 1 \mathrm{~b}$ replacing biotite layer-by-layer in large chloritized biotite grains shows on average $\mathrm{XFe}^{3+}$ similar to $\mathrm{Chl}$ b after biotite in sample ZA16-84 (25-27\%, Table 2 and Fig. 8c), higher than Chl1a found in sharp contact with biotite and at the rims of amphibole and biotite (20-25\%, Fig. 9e).

In discretely deformed samples, Chl1 and $\mathrm{Chl} 2$ have contrasted $\mathrm{XFe}^{3+}$ ratios (Chl1 of 22-28\% in ZA16-78, 22-23\% in ZA16-82, Chl2 of $\sim 30 \%$, Fig. 10d-f). The $\mathrm{XFe}^{3+}$ contrast between Chl1 and Chl2 is sharp, as in $\mathrm{Al}, \mathrm{Mg}$ and Fe maps (Fig. 6d, e). As for other major cations, the $\mathrm{Fe}^{3+}$ content is more heterogeneous in Chl1 (22.5 to 27.8\%) than in Chl2 (29-30\% or $31-33 \%$ Fig. 10c). In sample ZA16-78 only, a slight and gradual change of $\mathrm{XFe}^{3+}$ from Chl1 to Chl 2 values is observed over $1 \mu \mathrm{m}$ close to the Chl1-Chl2 boundary (Fig. 10c). This is consistent with a patchwork of compositions of both Chl1 and Chl2 types observed close to fractures (Fig. 6d). Inversely, $\mathrm{XFe}^{3+}$ varies sharply from Chl1 to Chl2 in sample ZA16-82 (Fig. 10f).

In mylonites $\mathrm{B} 10-31$, the average $\mathrm{XFe}^{3+}$ ratio is similar in Chl1 flakes and Chl2 inside and around cracks (20-24\%, Fig. 11e) but the values vary $(2-3 \%)$ along one single transect crossing several chlorite crystallites (Fig. 11e), following the patchy zoning observed in composition maps (Fig. 6i). In mylonite ZA16133, where the compositional difference between Chl1 and Chl2 is strong (Fig. 6e), the difference in $\mathrm{XFe}^{3+}$ between Chl1 (20-21\%) and Chl2 (27-28\%) is also high (Fig. S3b, c in Supplementary Material).

Table $2 \mathrm{XFe}^{3+}$ ratios obtained for equivalent areas by STEM-EELS and STXM-XANES. Line scans and stacks by STXM often include different generations of chlorite which explains their variability (see text for details).

\begin{tabular}{|ccccc|}
\hline Sample & Mineral & Line/Stack/Frame & Fe3+ STXM (\%) & Fe3+ EELS (\%) \\
\hline ZA16-119-1 & chl & linescan 161 & 20 & $20.6-21$ \\
Bt-Chl FIB & chl & linescan 163 & 23 & $20-21$ \\
& chl & stack 1 & 25 & 23 \\
& corrensite-like & stack1 & 70 & too small \\
& bt & linescan 170 & 25 and 30-60 locally & $24-25$ \\
\hline ZA16-119-2 & Chl & linescan 17 & 21.4 & $19.2-20.6$ \\
Amph-Chl FIB & Amph & stack 21 & 17 & $17.5-19.8$ \\
& Chl & stack 21 & 22 & $18.8-20$ \\
\hline ZA16-84-1 & Chl & stack 350 & 23 & $20-22$ \\
Amph-Chl FIB & Amph II & stack 351 & $43-50$ & $34-35$ \\
& Amph & stack 352 & $20-23$ & $21-24$ \\
\hline ZA16-84-2 & Bt & linescan 223 & 35 & \\
Bt-Chl FIB & Chl & linescan 223 & 26 & 20 \\
& Bt & linescan 234 & $31-32$ & 32 \\
& Chl & linescan 234 & 25 & 27 \\
& Chl & linescan 236 & 25 & 25 \\
\hline ZA16-79 & & linescan 53 & 18 et 22-24 & $21.2-23$ et 25-26 \\
& & linescan 54 & 26 & \\
& & linescan 55 & $19-20$ et 25 & $20-22$ et 26 \\
\hline
\end{tabular}

\section{DISCUSSION}

\subsection{Chloritization reaction mechanisms and their effect on chlorite compositional heterogeneity at microscale}

The existence of two types of chloritebiotite boundaries and the different features at the nanoscale among chlorite replacing biotite, chlorite replacing amphibole or newly crystallized chlorite are consistent with the existence of two compositional groups of Chl1 (Chl1a and Chl1b) and a group of Chl2, in different microstructural positions and suggests

\begin{tabular}{|ccccc|}
\hline Sample & Mineral & Line/StacK/Frame & Fe3+ STXM (\%) & Fe3+ EELS (\%) \\
\hline ZA16-78 & Chl1 & stack 023 & $22.5-25.7$ & $21.7-24$ \\
& Chl2 & stack 023 & 29 & 27 \\
& Ch12 & linescan 27 & $26-27.8$ & $25-26.4$ \\
& Chl2 & linescan 34 & 29.5 & 26.4 \\
\hline ZA16-82 & chl1 & linescan 86 & 22 & $21-24$ \\
& chl1 & linescan 87 & 23 & $21-24$ \\
& chl2 & linescan 89 & & 23 \\
& chl2 & linescan 90 & $31.7-33$ & 32 \\
\hline B10-31-1 & Ch11 & linescan 5 & $21-22.4$ & $19-20$ \\
& Chl1 & linescan 6 & $24-24.6$ & \\
& Ch11 & linescan 8 & $21-22.8$ & $20-24$ \\
& Chl1 & linescan 9 & 23.2 & $21.8-25.4$ \\
\hline B10-31-2 & Chl2 & linescan 121 & $20-21.6$ & $18-20$ \\
& Chl2 & linescan 122 & $19-22$ & $18-20$ \\
& Chl2 & linescan 124 & $21.7-22.8$ & $20.5-21$ \\
& Chl2 & linescan 125 & 22.7 & \\
\hline ZA16-133 & Chl1 & linescan 91 & 21.5 & $15-20$ \\
& Chl2 & linescan 92 & 27.9 & 30 \\
& Chl1 & linescan 93 & 20.4 & $19-24$ \\
& Chl2 & linescan 95 & 27.3 & $26-27.6$ \\
\hline
\end{tabular}

different mechanisms of chlorite crystallization. Three concurring mechanisms of crystallization controlling the compositional heterogeneity of chlorite are observed here: coupled dissolutionreprecipitation, layer-by-layer biotite replacement and direct precipitation from a free fluid; each leaving a distinct fingerprint.

The replacement of both amphibole and biotite at biotite rims by Chlla occurs by progressive dissolution-precipitation, triggered by fluid percolation, as indicated by: 
i) the sharp structural change at the Chl1aamphibole interface (Fig. 7f),

ii) Chl1a sheets progressively penetrating amphibole (Fig. 7c),

iii) the localisation of chlorite along amphibole cleavages (Fig. 5d, 6a), cleavages acting as privileged fluid pathways,

iv) the sharp and concordant boundary between differently-oriented chlorite and biotite rims (sample ZA16-119, second type of chloritebiotite boundary, Fig. 9b, i),
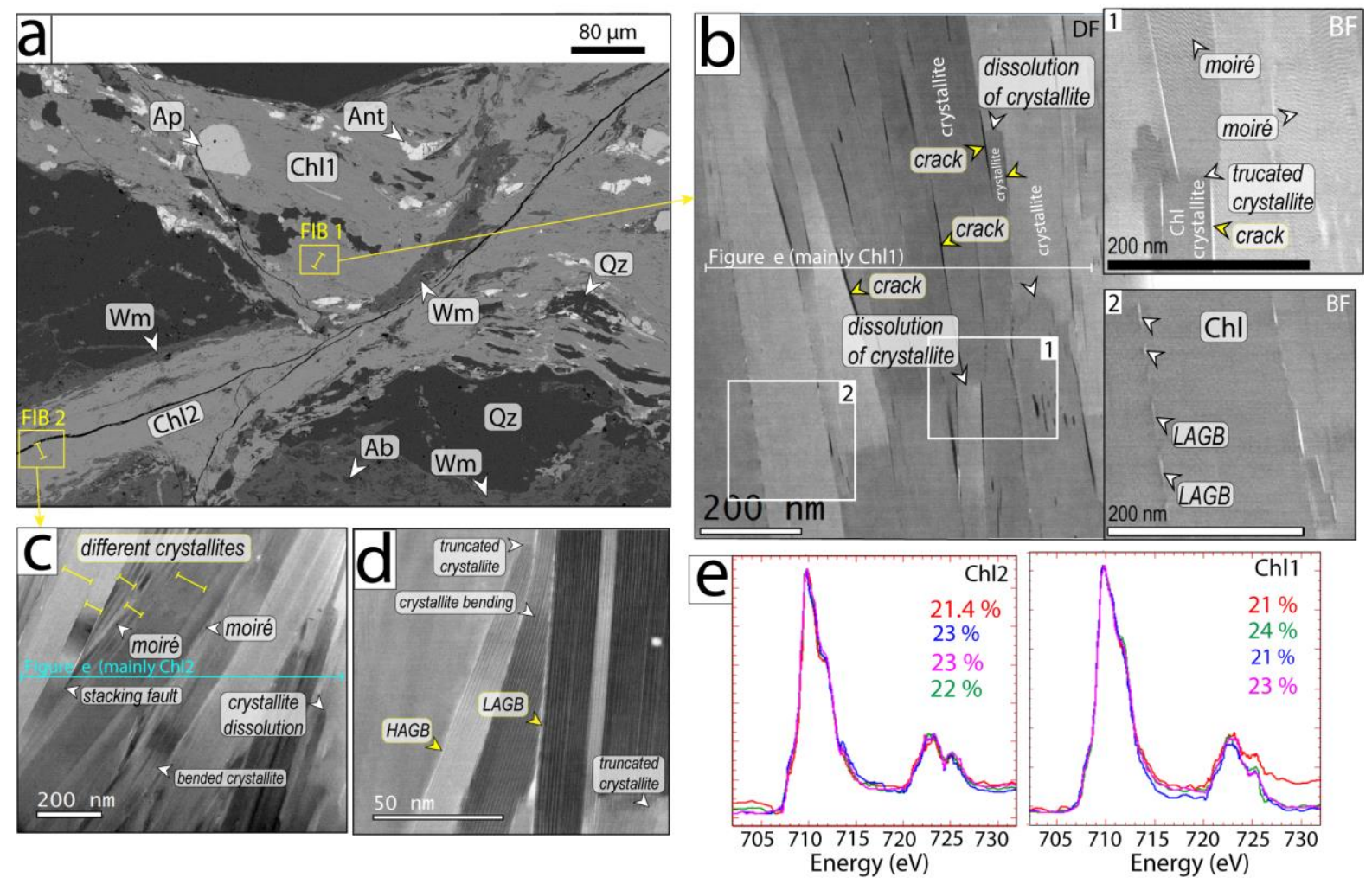

Figure 11 BSE, STEM images and $\mathrm{XFe}^{3+}(\%)$ estimates in chlorite of mylonites (sample B10-31). (a) Location of the two FIB foils (in chlorite flakes where mainly Chl1 is observed and around crack where mainly $\mathrm{Chl} 2$ is observed) in BSE image corresponding to the composition map of Figure 6i. (b) STEM image of chlorite flakes in FIB section. (c) and (d) STEM images of chlorite around cracks (mainly Chl2) in FIB foil. (e) Raw iron spectra for Chl1 and Chl2-rich transects. The variation of $\mathrm{XFe}^{3+}(\%)$ along a single transect in each chlorite is reported with coloured numbers (corresponding to different coloured spectra). DF: dark field, BF: bright field.

Layer-by-layer replacement of biotite is hypothesized for Chllb. Chlorite Chllb replacing biotite in biotite grains (first type of chlorite-biotite interface) exhibits nanostructures and composition different from Chl1a (Fig. 8a, b, 9b, f) and a higher compositional heterogeneity (e.g. Fig. 6c). Such heterogeneity is acquired during the chloritization reaction, since biotite relicts are homogeneous (Table 1). The differences between Chl1b and Chlla and the fact that $\mathrm{Chl}$ b/corrensite-like sheets in altered biotite v) the similar compositions of chlorite at biotite rims and Chlla in amphibole.

Furthermore, triangular planar defects similar to LAGB indicating that chlorite formed by precipitation (Kogure and Murakami 1998) are observed in Chlla (at amphibole and at biotite rims, Fig. 7c, 9j and Fig. S2c). Dissolutionprecipitation may explain the limited transport of $\mathrm{Al}$ as well as the homogeneity of Chlla relative to $\mathrm{Chl} 1 \mathrm{~b}$ in the case of amphibole chloritization. 
with K loss, generally associated with large outflow of ions (Veblen and Ferry 1983). In our samples, both mechanisms are observed within 30-50 nm. Chllb likely formed by a combination of the two, which is consistent with cations inflow from fluid shown by mass balance estimates (Fig. S4 in Supplementary Material, Yuguchi et al. 2015). Corrensite-like sheets alternating with chlorite translates at microscale by isolated packets of chlorite sheets and K-rich layers in biotite. This suggests that brucitic layers are transitional between biotite and chlorite, in agreement with previously described mechanisms of biotite chloritization (e.g. Veblen et al., 1983; Banfield and Eggleton, 1998) and the transitional character of corrensite, generally described as a metastable product between smectite and chlorite (Drits et al., 2011; Kogure et al., 2013).

Variations in $\mathrm{XFe}^{3+}$ ratios between Chl1a et Chllb may also reflect different chloritization mechanisms. If the octahedral layer of biotite (hosting $\mathrm{Fe}^{3+}$ ) is preserved during layer-by-layer biotite chloritization without altering the oxidation state of $\mathrm{Fe}, \mathrm{Fe}^{3+}$ is inherited from the parent mineral (as advocated by Aja, 2019). In contrast, during dissolution-reprecipitation, the $\mathrm{XFe}^{3+}$ ratio of the neo-formed minerals is influenced by the redox potential of the fluid involved in the chloritization reaction (e.g. Wigley et al., 2012). Corrensite-like sheets in altered biotite (Fig. 9bf) and variations of $\mathrm{XFe}^{3+}$ in chlorite indicate variable supply of the required $\mathrm{Fe}$ and $\mathrm{Mg}$, consistent with inferred nanoscale mechanisms of chlorite growth. At microscale, this translates as variable chlorite composition. Layer-bylayer replacement is favoured with smaller fluid availability (Kogure and Murakami 1998) and implies that fluid composition is more sensitive to interactions with minerals, resulting in the high compositional heterogeneity of Chllb compared to Chl1a (Fig. 5g, h, 6a, c, 9e). The predominance of one mechanism for biotite chloritization at nanoscale therefore implies variations in fluid supply (Yuguchi et al. 2015) which affects equilibrium length scales and mineral replacement at microscale.

In deformed samples, evidence is found for all three mechanisms of chlorite crystallisation. In discretely deformed samples, microstructures preserved outside fractures suggest that mineral reaction mechanisms are similar to those of undeformed samples. The very sharp boundary between $\mathrm{Chl} 1$ and $\mathrm{Chl} 2$ seen both in composition and nanofeatures indicates no (sample ZA16-82) or little (sample ZA16-78) replacement of Chl1 by Chl2: Chl2 directly precipitated from a free fluid in fractures. The fact that a new chlorite (Chl2) forms without recycling Chl1 implies that fluid is limited to fracture, without interacting with Chl1 composition in the matrix. Hence, a relatively high fluid supply at $\mathrm{Chl} 2$ growth site is required and explains the homogeneous composition of Chl2 over microns, in contrast to Chl1.

In mylonites, a variety of nanostructures as angular misorientations and high angle grain boundaries attest of intra-grain strain and chlorite crystallite replacement. High angle grain boundaries have been observed in illite (Buatier et al., 2012) and related to white mica replacement. The truncated borders rimmed by nanopores (inset 1 in Fig. 11b) also suggest partial dissolution of chlorite crystallites and reaction-induced porosity formation (see Putnis et al. 2002). Such nanostructures and the presence of nanoprecipitates in Chll and their absence in $\mathrm{Chl} 2$ are associated at microscale to partial replacement of Chl 1 by Chl 2 by coupled dissolution-reprecipitation. This results in the patchy compositional pattern formed by Chl1Chl2 observed in major elements and $\mathrm{XFe}^{3+}$ at microscale (Fig. 6f-i). Chl1 is replaced in mylonites up to 500-600 $\mu \mathrm{m}$ away from the crack rims (e.g. Fig. 6f, i). The high density of LAGB observed in Chl2 supports the fact that $\mathrm{Chl} 2$ grew from a solution. The terminations of the brucite layers of chlorite may be reflected in the compositional variations of $\mathrm{Chl} 2$ at microscale (Kogure and Murakami 1998).

Hence, the compositional heterogeneities in chlorite at microscale appear to be controlled by reaction mechanisms at the nanoscale, evolving with deformation and microstructural site. These heterogeneities are strongly influenced by fluid availability at the reaction site, with chlorite from dissolutionreprecipitation being more homogeneous than chlorite grown from layer-by-layer biotite replacement.

\subsection{Strain and reaction-related porosity formation during and after chlorite growth}

The amount of fluid available at the reaction site is controlled by porosity, permeability and advancement of hydration 
reactions. Along the strain gradient of our sample series, mechanisms of nanoscale porosity formation may be related to both reaction-induced strain (volume change) and external strain. In granodiorite ZA16-84, porosity is observed at the Chlla-amphibole interface (Fig. 7f). It is unlikely that this porosity formed during the cutting of the FIB foil since it is not observed in chlorite or amphibole far from the interface. Assuming Al is mobile, mineral compositions (see Table 1, sample ZA16-84) suggest that the replacement reaction involves one mole of chlorite (p.f.u.) for each mole of amphibole (p.f.u.), following Eq. 1:

$$
\begin{aligned}
& \left(\mathrm{Ca}_{1.67} \mathrm{Na}_{0.33} \mathrm{~K}_{0.09}\right)(\mathrm{Fe}, \mathrm{Mg})_{4.80} \mathrm{Al}_{0.28}\left(\mathrm{Al}_{0.91} \mathrm{Si}_{7.09}\right. \\
& \mathrm{O}_{22}(\mathrm{OH})_{2}+3 \mathrm{H}_{2} \mathrm{O}+0.60 \mathrm{Al}_{2} \mathrm{O}_{3}= \\
& (\mathrm{Mg}, \mathrm{Fe})_{4.50} \mathrm{Al}_{1.16}\left(\mathrm{Si}_{2.79} \mathrm{Al}_{1.21}\right) \mathrm{O}_{10}(\mathrm{OH})_{8}+4.30 \mathrm{SiO}_{2} \\
& +1.67 \mathrm{CaO}+0.16 \mathrm{Na}_{2} \mathrm{O}+0.05 \mathrm{~K}_{2} \mathrm{O}+0.30(\mathrm{Mg} \text {, } \\
& \mathrm{Fe}) \mathrm{O} \text {. }
\end{aligned}
$$

Given that the molar volume of amphibole endmembers (magnesio-hornblende: $274 \mathrm{~cm}^{3} / \mathrm{mol}$ and actinolite: $276 \mathrm{~cm}^{3} /$ mole respectively) is higher than the molar volume of chlorite (211 $\mathrm{cm}^{3} / \mathrm{mol}$ for clinochlore), the volume change of the chloritization of amphibole (Eq. 1) is negative around $-65 \mathrm{~cm}^{3} / \mathrm{mole}$. If $\mathrm{Al}$ is assumed immobile, the molar ratio for amphibole to chlorite replacement is 2:1 according to Eq. 2:

$2\left[\left(\mathrm{Ca}_{1.67} \mathrm{Na}_{0.33} \mathrm{~K}_{0.09}\right)(\mathrm{Fe}, \mathrm{Mg})_{4.80} \mathrm{Al}_{0.28}\left(\mathrm{Al}_{0.91} \mathrm{Si}_{7.09}\right.\right.$ $\left.\mathrm{O}_{22}(\mathrm{OH})_{2}\right]+2 \mathrm{H}_{2} \mathrm{O}=(\mathrm{Mg}, \mathrm{Fe})_{4.50} \mathrm{Al}_{1.16}\left(\mathrm{Si}_{2.79}\right.$ $\left.\mathrm{Al}_{1.21}\right) \mathrm{O}_{10}(\mathrm{OH})_{8}+11.40 \mathrm{SiO}_{2}+3.34 \mathrm{CaO}+$ $0.33 \mathrm{Na}_{2} \mathrm{O}+0.09 \mathrm{~K}_{2} \mathrm{O}+5.10(\mathrm{Mg}, \mathrm{Fe}) \mathrm{O}$.

and the volume change is more negative $(\sim-130$ $\mathrm{cm}^{3} /$ mole for Eq. 2). The formation of pores is therefore interpreted as reaction-induced, as described for K-feldspar replacement by Putnis (2002) and Putnis and John (2010). The formation of pores is also consistent with the presence of silica rims between amphibole and chlorite (e.g. Fig. 4c, 5g), interpreted as immediately filling the newly-created porosity. The thin $\mathrm{Fe}^{3+}$-rich amphibole band (Amph II in Fig. 7g) also highlights the dissolutionprecipitation reaction front (where porosity forms) at the amphibole (Amph I)-chlorite interface. Estimating the volume change for biotite chloritization at biotite rims (Chlla) is more difficult since it probably involves cation inflow from concomitant reactions (e.g., amphibole dissolution) in variable proportions and may be compensated by layer-by-layer chloritization of biotite.
In biotite chloritized layer-by-layer (samples ZA16-84 and ZA16-119), the isolated widening of the interlayer (Fig. 9d) mimics the microcleavages produced by basal slip of the interlayer site (Baños et al. 1983; Amouric 1987), consistently with leaching of $K$ from the biotite interlayer during chloritization (Fig. 5e). Local dissolution provided the space necessary for the growth of the rare chlorite sheets in littlealtered biotite (Fig. 9c), as proposed by Banfield and Eggleton (1988). In sample ZA16-119, ripplocations as described by Aslin et al. (2019) are observed in biotite but not in chlorite, although these authors suggest that chlorite is more prone to develop ripplocations than biotite. It is unlikely that ripplocations are related to the FIB foil preparation since they are only found in biotite, even when biotite and chlorite alternate at nanoscale (Fig. 8b). More precisely, ripplocations are observed in biotite close to areas where biotite is replaced by chlorite or chlorite + corrensite-like sheets (samples ZA16-84 and ZA16-119, Fig. 8b, 9b), suggesting that ripplocations formed before being reached by layer-by-layer replacement of biotite. The facts that biotite interlayer opening and ripplocations have been observed also in biotite with little chloritization (Fig. 9c, d and Aslin et al., 2019) suggest that these defects were, at least in a first stage, induced by an external deformation. Some ripplocations evolved into pores (complete separation of TOT sites, beyond interlayer widening). $\mathrm{Fe}^{3+}$-rich layers correspond to crystallization of corrensite-like and chlorite sheets in the biotite alteration reaction zone (as observed by Parneix et al. 1985). The high $\mathrm{XFe}^{3+}$ ratios in chlorite + corrensite-like crystals areas are also observed around ripplocations forming a patchy texture (Fig. 9e). This suggests that biotite alteration takes place preferentially, or initiates, around ripplocations. At the microscale, patchy, heterogeneous composition is observed in maps where ripplocations are located (e.g. Fig. 6c). Hence, ripplocations may provide the porosity necessary to trigger chloritization reactions explaining the microscale patchy texture.

In biotite, the combination of two layerby-layer biotite chloritization mechanisms observed in our samples (see 7.1) is consistent with a small volume decrease, as proposed by Yuguchi et al. (2015). Overall, a volume decrease is also supported by the presence of nanometric secondary precipitates as silica and 
Ti-bearing phases (Fig. 4c, 6c 8b) and the deformation of biotite sheets around chloritized areas (Fig. 9b, f). Local heterogeneity in the availability of fluid may influence the mechanism of chlorite growth (Yuguchi et al., 2015) and eventually the volume changes, favouring or inhibiting creation of porosity.

In discretely deformed samples and in mylonites, some of the nanocracks at crystallite rims may have formed during the FIB foil preparation, yet textural evidence shows that nanocracks pre-existed sample preparation. Nanocracks are (i) partially filled with $\mathrm{Chl} 2$, suggesting fluid circulation may have reduced fracture permeability (see Morad et al. 2011), (ii) the sole discontinuities observed in chlorite grains (without intracrystalline porosity) and (iii) mainly observed in deformed samples. Therefore at least part of these nanocracks formed during a regional deformation event or

\section{UNDEFORMED GRANITOID \\ Percolation of fluid at grain boundaries and in grain defects. Fluid in isolated pockets}

Heterogeneous chlorite crystallization
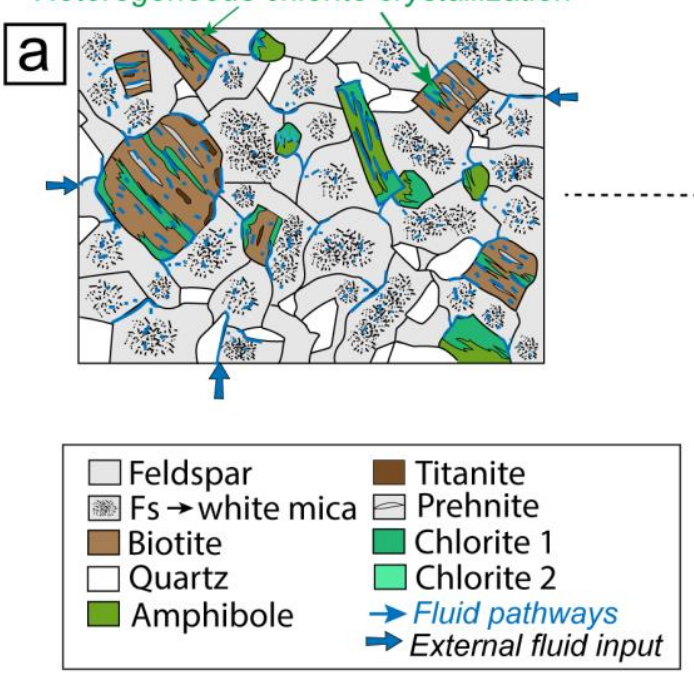

STRAIN opened on existing weak boundaries and pores. Nanostructures (e.g. moirés) also suggest that external strain contributed to the formation of porosity in mylonites. Nanoporosity observed at the rims of dissolved crystallites and the alternating nanoprecipitate-bearing and depleted chlorite crystallites indicate higher chlorite recrystallization than for other sample types. This corresponds to patchy replacement of Chl1 by Chl 2 at micrometric scale (Fig. 6f-i and 14 in the Supplementary Material). Hence, while early fluid-rock interaction and chloritization reactions create additional porosity at the grain and sub-grain scale, later external deformation and reactions may open cracks from the nanoscale (at crystallite boundaries) to the $\mathrm{mm}$ scale, triggering further metamorphic transformations.

\section{DISCRETE DEFORMATION:}

Fluid mainly channelized in

$\mathbf{m m}$-sized fractures

Crystallization of new chlorite

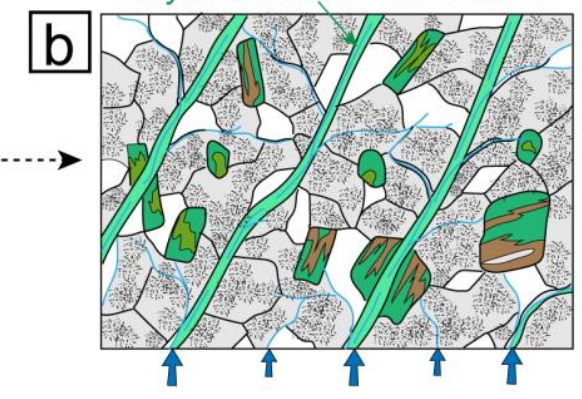

MYLONITIZATION

Partial fluid channelization, more pervasive interaction with the matrix Re-crystallization of chlorite

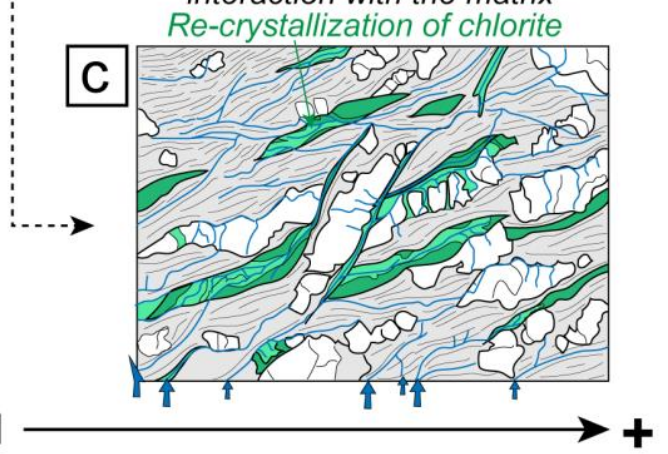

Figure 12 Sketch summarizing the modalities of fluid percolation with increasing strain evinced from nanostructures, compositional variability and mineral reaction. (a) In the underformed samples fluid percolates along grain boundaries and through reaction-induced porosity resulting in high and local variability of chlorite composition. (b) In discretely deformed samples, fluid is completely channelized in fractures and local equilibria are preserved outside fractures. (c) In brittle-ductile low-grade mylonites, fluid is partly channelized in cracks but succeed in percolating into the matrix up to hundreds of $\mu \mathrm{m}$ from the cracks because of well-connected nanodefects. 


\subsection{Changes in element mobility with evolving microstructures}

Different scales of element mobility are observed with increasing strain, pointing out to different mechanisms of fluid percolation.

In undeformed samples, reactions appear to occur in situ, by pseudomorphic replacement with low fluid supply and minimum mobility for elements other than $\mathrm{Ca}$ and $\mathrm{K}$. According to equation 1, amphibole chloritization releases small amounts of $\mathrm{Ca}, \mathrm{Na}$, $\mathrm{Fe}-\mathrm{Mg}$ and $\mathrm{Si}$. If $\mathrm{Al}$ is considered immobile (Eq. 2 ), the reaction releases larger amounts of $\mathrm{Ca}$, $\mathrm{Na}, \mathrm{Fe}-\mathrm{Mg}$ and $\mathrm{Si}$. The principal $\mathrm{Al}$ source for chlorite growth is the breakdown of plagioclase as suggested by the higher chloritization degree observed in biotite and amphibole adjacent to altered plagioclase (e.g. Fig. 4a, 10g). Aluminium is therefore not entirely immobile during chloritization since it has to be transferred to chlorite growing site (consistently with the interpretations of Parneix et al. 1985; Nishimoto and Yoshida 2010; Hövelmann 2010). Mass balance estimates from composition maps show that if biotite is taken solely as the initial reactive system, a systematic increase of 20-30 mol.\% of $\mathrm{Fe}, \mathrm{Al}$ and $\mathrm{Mg}$ content is needed to transform biotite into chlorite (Fig. S4a,b and e). However, if amphibole and plagioclase are included in the initial reactive system, elemental variations are minimal (Fig. S4c, d and f). Hence, the biotite amphibole - plagioclase assemblage appears to destabilize to phyllosilicate-rich assemblages with essentially closed-system behaviour for $\mathrm{Al}, \mathrm{Fe}, \mathrm{Mg}$ and $\mathrm{Si}$. Ti appears immobile, as seen in SEM images showing Ti-bearing phases forming in situ during biotite and amphibole breakdown (e.g. Fig. 4c, e). The decoupled behaviours of $\mathrm{Mg}$ and $\mathrm{Fe}$ in areas of biotite and amphibole chloritization (Fig. $5 \mathrm{~g}, \mathrm{~h}$ ) point out to different mobility with very close sources and sinks. The result is micrometric heterogeneities in chloritized biotite and amphibole grains with out-of-equilibrium mechanisms (layer-by-layer replacement) or local equilibria between varied reaction products (chlorite $+\mathrm{wm}$ or $\mathrm{chl}+\mathrm{pr}+$ $\mathrm{qz}$ or chl $+\mathrm{ttn}$ or chl $+\mathrm{rt}$ etc.). Calcium and potassium appear much more mobile. A loss of at least 50 mol.\% of $\mathrm{K}$ and a net gain $>250$ mol.\% of $\mathrm{Ca}$ are suggested by local bulk composition (Fig. S4). Calcium is systematically added to the system: a circulation of $\mathrm{Ca}^{2+}$-rich fluids at a mm scale (or more) is consistent with the presence of calcite, apatite and prehnite disseminated in the matrix of altered granite in addition to calcic phases attributed to dissolution-transport-precipitation reaction mechanisms from the original plagioclase. Potassium is generally expelled during biotite alteration, consistent with the dissolution of the interlayer site of biotite during chloritization (Fig. 5e, 9f, i). The lengthscale of $\mathrm{K}$ mobility is variable with a minimum around $200 \mu \mathrm{m}$ (Fig. 5f, i, 6b and Fig. S4 of the Supplementary Material). The sink for $\mathrm{K}$ removed from biotite (where white mica is not observed) may be white mica rimming chlorite flakes (Fig. 5i and f) or white mica after feldspar breakdown in matrix (Fig 5b-f), or a combination of both. The pseudomorphic breakdown of alkali feldspar and zoned magmatic plagioclase into aggregates of white mica + albite, as well as the co-existence of reactants (biotite, amphibole) and products (chlorite, anatase, titanite and secondary quartz) pseudomorphically replacing parent minerals (e.g; Fig. 4c, d, 10g), indicate little element transport, preserving heterogeneities from the protolith during alteration. Micrometric variations of reaction products (Chl \pm white mica, chlorite + rutile or titanite, chlorite \pm prehnite) in apparent textural equilibrium point out to micrometric scales of equilibria. It is concluded that in undeformed samples, the magmatic assemblage is reactive to percolating fluid but element mobility is limited and heterogeneities at the micron scale are mainly controlled by reaction types and local fluid composition buffered by local mineral assemblages. As replacement reactions are incomplete and acting on micrometric scales, yet pervasively in the rock, reactions fronts are very sharp and fingered: alteration appears diffuse in the field.

In discretely deformed samples, feldspar is more altered around microcraks than in undeformed samples (Fig. 3d), indicating that micro-fracturing triggered feldspar breakdown reactions in addition to the creation of edge pits. Similar differences between Chl1 and Chl 2 in terms of major element compositions and iron speciation (e.g. Fig. 10c) indicate that iron speciation in chlorite is primarily dictated by reactions of chlorite growth for Chl2 (and the redox state of the fluid involved) rather than by growth mechanisms or later oxidation as for Chllb. $\mathrm{XFe}^{3+}$ ratios are also consistent with 
values generally obtained for chlorite formed in the temperature range of $250-350^{\circ} \mathrm{C}$ (Vidal et al. 2006; Muñoz et al. 2006) and indicate more oxidizing conditions during fracturing than during early pervasive alteration (Table 2). In addition, the very sharp boundary between Chl1 and Chl2 indicates very little element transfers across fracture walls. $\mathrm{XFe}^{3+}$ and chemical composition homogeneous over a larger spatial scale in $\mathrm{Chl} 2$ (e.g. Fig. 6e) suggest higher element mobility in fractures than in the surrounding matrix. In sample ZA16-78, gradual changes of $\mathrm{XFe}^{3+}$ and composition of Chl1 close to fracture walls (Fig. 10c) point out to partial replacement of $\mathrm{Chl1}$ by $\mathrm{Chl} 2$ at the very proximity of the fracture (Fig. 6d), and thus suggest limited fluid infiltration across fracture wall.

In mylonites, alteration is pervasive and partly occurred during deformation as attested by the microtextural position of phyllosilicates. Chlorite replacement is higher in mylonites than in undeformed and discretely deformed samples (outside fractures, Fig. S1a), pointing out to an evolution of element mobility with increasing strain. However, chlorite composition is not homogenized, despite the high strain. Incomplete re-equilibration is consistent with the preservation of two groups of U-Pb ages in accessory minerals of discretely deformed samples (Airaghi et al. 2020). Incomplete composition reset has also been observed in quartz grains of high strain zones of mylonites, where the inherited $\mathrm{Ti}$ content is preserved in quartz grains (Bestmann and Pennacchioni, 2015). Although chlorite and quartz have different behaviors in mylonites, this suggest that compositional heterogeneities can be preserved even in zones of high strain.

\subsection{Implications for the scale and mechanisms of fluid percolation in undeformed and deformed granites}

The variability from undeformed rocks to mylonites in the extent of mineral transformation in chlorite composition, microstructures and nanostructures suggest an evolution in fluid supply and in the scales of fluid percolation in the Bielsa massif. In the underformed granitoid, high chlorite heterogeneity, incomplete reactions and low element mobility are explained by absence or local equilibrium due to the percolation of an initially low amount of fluid, which composition is therefore buffered by local mineral reactions and assemblages.

Reaction products and pores at the chlorite-amphibole rims and in biotite during biotite and amphibole chloritization (see 4) and K-feldspar sericitization (e.g. Nishimoto and Yoshida 2010) suggest that fluids percolate efficiently at grain boundaries at this stage, with increasing reactive surface area due to grain size reduction. This provides the space for fluids to percolate into the anhydrous protolith and trigger further negative-volume chloritization reaction, as suggested for a variety of context and mineral reactions (Morgan and Holzman 2005; Putnis,2002; Putnis and John 2010; Morad et al. 2011). The poor interconnection of defects such as ripplocations along the $c$ axis of biotite prevents homogenisation of the fluid resulting in heterogeneous chlorite composition (and structure) (see section 7.1). Note that porosity is also produced by the breakdown of feldspar (Putnis and Austrheim 2010; Plümper et al. 2017). It is therefore supposed that the percolating fluid remained isolated in "pockets", reactions being similar across samples but in small reservoirs temporally isolated that promoted compositional heterogeneity of both fluid and chlorite. This process may explain the characteristics of the pre-kinematic hydration event observed in numerous crystalline massifs of the Axial zone of the Pyrenees (Cathelineau 1986; Boutin et al. 2016).

In discretely deformed samples, the element mobility was sufficiently high in fractures to allow the homogenisation of $\mathrm{Chl} 2$ composition and to reach larger equilibria scale over several $\mathrm{mm}$. This points out to advection of fluid with constant composition into fractures, with opening pores in Chl2 (e.g. Fig. $10 \mathrm{a}, \mathrm{b})$. The lack of mass transfer between fractures and rock matrix indicates that the fluid was sufficiently channelized to preserve compositional relicts of the altered protolith in the surrounding matrix (where pores are clogged in Chl1 flakes by secondary products as silica and titanite), allowing radiochronometric dating of former assemblages (as frequently observed, e.g. Cox et al. 1986; Ague 2011).

In mylonites, the partial replacement of Chl1 in flakes by Chl2 indicates that fluid percolated into the matrix, unlike in discretely 
deformed samples. At this stage, the fluid circulated into chlorite through cracks rimming chlorite crystallites from millimetric down to nanometric scale. Note that in mylonites, smaller average grain size (due to extensive chlorite recrystallization) increases the surface area of crystallite interfaces hosting nanofractures compared to other sample types. Crystallization of $\mathrm{Chl} 2$, via precipitation or replacement of Chl1 contributed to decreasing the permeability, moderating permeability generated during deformation (as observed by Morad et al. 2011 or experimentally by Tenthorey et al. 2006) and resulting in incomplete composition re-equilibration despite the high strain.

\subsection{Implications for the preservation} of low-grade metamorphic history in deformed Bielsa granitoid

Mineralogical transformations including chloritization reactions in undeformed samples are interpreted as prekinematic and Late to Post-Variscan, following the petrological and geochronological results of Airaghi et al. (2020). In deformed samples, Chl2 is either associated to fractures (in discretely deformed samples and in and around discrete, irregular cracks of mylonites) or in boundins of Chl1 elongated parallel to $\mathrm{S}$ (in mylonites). This suggest that $\mathrm{Chl} 2$ grew during a brittle-ductile deformation event (often observed in low-grade metagranitoids, Pec et al., 2012; Leyder et al., 2019) dated as Alpine (Airaghi et al., 2020). Differences of microstructures between discretely deformed samples and mylonites may represent an evolution: (i) in strain intensity, (ii) in lithology (possibly acquired during differential LateVariscan alteration) and/or (iii) in time (fractures being possible precursors of mylonites, e.g. Pennacchioni et al., 2007). In the latter case, fluid percolation and mineral transformation would have been enhanced by the Alpine fracturing stage, increasing strain localization up to metric scale (heterogeneous distribution of mylonitic corridors in the crystalline basement). In any case, in the undeformed Bielsa granitoids, static alteration, local mineral equilibria and composition heterogeneities in phyllosilicates due to local late-Variscan fluid percolation (Fig. 12a) was preserved during fracturing (Fig. 12b) or brittleductile flow (mylonitization, Fig. 12c) despite the high strain and grain size reduction. This preservation, observed in other greenschistfacies crystalline mylonites (e.g. Berger et al., 2017) is explained by intra and intergranular defects (from nanoscale to micrometric fractures) that control element mobility and reveal several degrees of fluid channelization (Fig. 12, c). Fluid channelization limits the Alpine syn-kinematic metamorphic overprint to portions of shear zones and fractured rocks up to the metric scale, preserving lentilles of undeformed Bielsa granitoid (e.g. Bellahsen et al., 2019). As such, the greenschist-facies Bielsa mylonites cannot seen as channels of extensive syn-kinematic fluid-mediated chlorite replacement at the meso and microscale.

\section{CONCLUSIONS}

Granitoids collected along a strain gradient in the Bielsa crystalline massif (Axial zone, Pyrenees) show pervasive Late to PostVariscan hydrothermal alteration in greenschist-facies conditions, incomplete chloritization reactions of biotite and amphibole, and feldspar breakdown by pseudomorphic replacement. This alteration is associated to low element mobility and high compositional heterogeneity of chlorite (included in $\mathrm{Fe}^{3+}$ content). Nanoporosity appears as isolated defects or ripplocations formed during chloritization. These features are related to variations of fluid-rock ratio in space and time, to different mechanisms of chloritization reactions as well as to isolation of the fluid in local reacting domains with specific composition. Grain boundary permeability and nanoscale porosity in crystals are sufficient for fluid to percolate and induce reactions crystallizing in situ neo-formed minerals from mobilized elements.

In the parts of the granitoid cross-cut by Alpine-age millimetric fractures, secondary chlorite grew from a free fluid in fractures only, while parts of the altered matrix outside fractures share similar characteristics with undeformed rocks. Only Alpine chlorite is homogenous, indicating that high element mobility was restricted to $\mathrm{mm}$-sized fractures. Channelization of fluids in fractures allowed persistence of local heterogeneities and incomplete reactions outside cracks. In mylonites, pervasive but partial replacement of Late-Variscan chlorite by Alpine chlorite occurs via dissolution-precipitation, resulting in 
a patchy chemical composition at micronscale. Chlorite composition is not homogenized despite the high strain. The abundant micrometric and nanometric defects at the boundary of chlorite crystallites allowed efficient fluid circulation in matrix at hundreds of $\mu \mathrm{m}$ from cracks, until crystallization of Alpine chlorite inhibited further percolation of fluid. Hence, in the Bielsa massif, a detailed multi-scale study of chlorite shows that fluid percolation is controlled by fracturing, porosity contrasts between fractures and the host rock, and by the interconnection of nanoporosity between crystallites. Like for chlorite in this study, the compositional heterogeneity and the extent of the replacement of other phyllosilicates along strain gradients in granitoids informs over the evolution of the fluid supply, reactive local composition and element mobility during deformation, since compositional heterogeneity is controlled by element influx and transport-limited mobility (e.g. depending on the ability of the fluid to percolate from fractures into the matrix). These parameters strongly influence the preservation of hydrothermal metamorphism over synkinematic fluid-rock interaction events in high strain zones, providing information on the entire metamorphic history of granitic rocks in

\section{REFERENCES}

Abd Elmola, A, Charpentier, D, Buatier, M, Lanari, P \& Monié, P (2017). Texturalchemical changes and deformation conditions registered by phyllosilicates in a fault zone (Pic de Port Vieux thrust, Pyrenees). Applied Clay Sciences, 144, 88-103.

Airaghi, L, Bellahsen, N, Dubacq, B, Chew, D, Rosenberg, C, Janots, E, Waldner, M \& Magnin, V (2020). Pre-orogenic upper crustal softening by lower greenschist facies metamorphic reactions in granites of the central Pyrenees. Journal of Metamorphic Geology, 38(2), 183204.

Airaghi, L, Warren, C J, de Sigoyer, J, Lanari, P \& Magnin, V (2018). Influence of dissolution/reprecipitation reactions on metamorphic greenschist to amphibolite facies mica ${ }^{40} \mathrm{Ar} /{ }^{39} \mathrm{Ar}$ ages in the Longmen Shan (eastern Tibet). orogens under greenschist-facies conditions. The detailed multi-scale investigation of phyllosilicate as chlorite also allows the timing of phyllosilicate growth relative to deformation to be clarified, in an effort to model the rheological behaviour of the rocks at different stages of the metamorphic history.

\section{ACKNOWLEDGEMENTS}

This study was founded by the CNRS-BRGMTOTAL 'OROGEN' project. We acknowledge the two reviewers and editor for their constructive comments. The STEM images were acquired using TEM national facility on the platform METSA. We also acknowledge Audrey Sauldubois for her support with the TEM at ICMN in Orléans. We thank David Troadec (University of Lille) and IEMN for FIB preparation and Michel Fialin, Nicolas Rividi and Omar Boudouma for their help with the electron microscopy at ISTeP. We also thank Benjamin Watts for his support on the PolLux beamline at the SLS PSI. We acknowledge Cyril Durand and Emily Lloret (University of Lille) for the support to the SLS PSI and Cladio Rosenberg of ISTeP (Sorbonne Université) and Holger Stünitz (University of Trømso and Orléans) for enriching discussions.

Journal of Metamorphic Geology, 36(7), 933-958.

Airaghi, L, Lanari, P, de Sigoyer, J \& Guillot, $S$ (2017a). Microstructural vs compositional preservation and pseudomorphic replacement of muscovite in deformed metapelites from the Longmen Shan (Sichuan, China). Lithos, 282-283, 262-280.

Airaghi, L, de Sigoyer, J, Lanari, P, Guillot, S, Vidal, O, Monié, P, Sautter, B, Tan, X. (2017b). Total exhumation across the Beichuan fault in the Longmen Shan (eastern Tibetan plateau, China): Constraints from petrology and thermobarometry. Journal of Asian Earth Sciences, 140, 108-121.

Ague, J J (2011). Extreme channelization of fluid and the problem of element mobility during Barrovian metamorphism, American 
Aja, S (2019). Excess functions of chlorite solid solutions and neoformation of $\mathrm{Fe}$ chlorites: Some implications of recent thermochemical measurements. American Mineralogist, 104, 232-243.

Amouric, M (1987). Growth and deformation defects in phyllosilicates as seen by HRTEM. Acta Cryst., B43, 57-63.

Aslin, J, Mariani, E, Dawson, K \& Barsoum, M W (2019). Ripplocations provide a nex mechanism for the deformation of phyllosilicates in the lithosphere. Nature Communications.

Aspandiar, M F \& Eggleton, R A (2010). Weathering of chlorite: I. Reactions and products in microsystems controlled by the primary mineral. Clays and Clay Minerals, 50(6), 685-698.

Banfield, J F \& Eggleton, R A (1988). Transmission Electron Microscope study of biotite weathering, Clays and Clay Minerals, 36(1), 47-60.

Baños, J O \& Amouric, M (1983). Interlayering and interlayer slip in biotite as seen by HRTEM. American Mineralogist, 68, 754-758.

Bautier, M D, Lacroix, B, Labaume, P, Moutarlier, V, Charpentier, D, Sizun, J P \& Travé, A (2012). Microtextural investigation (SEM and TEM study) of phyllosilicates in a major thrust fault zone (Monte Perdido, southern Pyrenees): impact on fault reactivation.

Bellahsen, N, Bayet, L, Denele, Y, Waldner, M, Airaghi, L, Rosenberg, C, Dubacq, B, Mouthereau, F, Bernet, M, Pik, R, Lahfid, A, Vacherat, A (2019). Shortening of the axial zone, Pyrenees: Shortening sequence, upper crustal mylonties and crustal strength. Tectonophysics, 766, 433-452.

Berger, A, Wehrens, P, Lanari, P, Zwingmann, H \& Herwegh, M (2017). Microstructures, mineral chemistry and geochronology of white micas along a retrograde evolution: An example from the Aar massif (Central Alps, Switzerland). Tectonophysics, 721, 179-195.
Bestmann, M., Pennacchioni, G., 2015. Ti distribution in quartz across a heterogeneous shear zone within a granodiorite: The effect of deformation mechanism and strain on Ti resetting. Lithos 227, 37-56.

Bourdelle, F, Beyssac, O, Parra, T \& Chopin, C (2018). Nanoscale chemical zoning of chlorite and implications for lowtemperature thermometry: Application to the Glarus Alps (Switzerland). Lithos, 314-315, 551-561.

Bourdelle, F, Benzerara, K, Beyssac, O, Cosmidis, J, Neuville, D R, Brown, G E Jr \& Paineau, E (2013). Quantification of the ferric/ferrous iron in silicates by scanning transmission X-ray microscopy at the $\mathrm{Fe} \mathrm{L}_{2,3}$ edges. Contribution to Mineralogy and Petrology, 166, 423-434.

Boutin, A, de Saint Blanquat, M, Poujol, M, Boulvais, P, de Parseval, P, Rouleau, C, Robert, J-F (2016). Succession of Permian and Mesozoic metasomatic events in the eastern Pyrenees with emphasis on the Trimouns talc-chlorite deposit. International Journal of Earth Science, 105, 747-770.

Cathelineau, M (1986). The Hydrothermal Alkali Metasomatism Effects on Granitic Rocks: Quartz Dissolution and Related Subsolidus Changes. Journal of Petrology, 27, 945-965.

Cox, S F, Etheridge, M A and Wall, V J (1986). The role of lfuids in syntectonic mass transport, and the localization of metamorphic vein-type ore deposits. Ore Geology Reviews, 2, 65-86.

De Andrade, V, Susini, J, Salomé, M, Beraldin, O, Rigault, C, Heymes, T, Lewin, E and Vidal, $\mathrm{O}$ Submicrometer Hyperspectral X-ray Imaging of Heterogeneous Rocks and Geomaterials: Applications at the $\mathrm{Fe}$ K-Edge Analytical Chemistry, 2011, 83, 4220-4227.

Fitz Gerald, J D and Stünitz, H. (1993). Deformation of granitoids at low metamorphic grade. I: Reactions and grain size reduction. Tectonophysics, 221, 269-297. 
Goncalves, P, Oliot, E, Marquer, D \& Connolly, A D (2012). Role of chemical processes on shear zone formation: an example from the Grimsel metagranodiorite (Aar massif, Central Alps); Journal of Metamorphic Geology, 30, 703-722.

Gueydan, F, Leroy, Y M, Jolivet, L, and Agard, P (2003). Analysis of continental midcrustal strain localization induced by microfracturing and reactionsoftening. Journal of Geophysical Research, 108(B2), 2064.

Hövelmann, J, Putnis, A, Geisler, T, Schmidt, B C \& Golla-Schindler, U (2010). The replacement of plagioclase feldspar by albite: observations from hydrothermal experiments. Contribution to Mineralogy and Petrology, 159, 43-59.

Ingles, J, Lamouroux, C, Soula, J-C, Guerrero, $\mathrm{N}$ and Debat, P (1999). Nucleation of ductile shear zones in a granodiorite under greenschist facies conditions, Néouvielle massif, Pyrenees, France. Journal of Structural Geology, 21, 555576.

Lanari, P, Vho, A, Airaghi, L, Centrella, S (2019). Quantitative compositional mapping of mineral phases by electron probe micro-analyser. Geological Society, London, Special Publications, 478, 39-63.

Lanari, P, Vidal, O, De Andrade, V, Dubacq, B, Lewin, E, Grosch, E, Schwartz, S (2014). XMapTools: a MATLABbased program for electron microprobe $\mathrm{X}$-ray image processing and geothermobarometry. Computers \& Geosciences 62, 227-240.

Leydier T. et al., 2019. On the petrology of brittle precursors of shear zones - An expression of concomitant brittle deformation and fluid-rock interactions in the "ductile" continental crust J. metamorphic Geol. 37:11291149

Oliot, E, Goncalves, P and Marquer, D (2010). Role of plagioclase and reaction softening in a metagranite shear zone at mid-crustal conditions (Gotthard Massif, Swiss Central Alps). Journal of Metamorphic Geology, 28, 849-871.
Kogure, T, Drits, V A and Inoue, S (2013). Structure of mixed-layer corrensitechlorite revealed by high-resolution transmission electron microscopy (HRTEM). American Mineralogist, 98, 1253-1260.

Kogure, T and Murakami, T (1998). Structure and formation mechanisms of lowangle grain boundaries in chlorite. American Mineralogist, 83, 358-364.

Jamtveit, B and Austrheim, H (2010). Metamorphism: the role of fluids. Elements, 6, 153-158.

Jonas, L, John, , King, H E, Geisler, T and Putnis, A (2014). The role of grain boundaries and transient porosity in rocks as fluid pathways for reaction front propagation. Earth and Planetary Science Letters, 386, 64-74.

Maggi, M, Rossetti, F, Ranalli, G and Theye, T (2014). Feedback between fluid infiltration and rheology along a regional ductile-to-brittle shear zone: The East Tenda Shear Zone (Alpine Corsica). Tectonics, 33, 253-280.

Mancktelow, N.S., 2002. Finite-element modelling of shear zone development in viscoelastic materials and its implications for localisation of partial melting. J. Struct. Geol. 24, 1045-1053.

Mandal, N., Misra, S., Samanta, S.K., 2004. Role of weak flaws in nucleation of shear zones: an experimental and theoretical study. J. Struct. Geol. 26, 1391-1400.

Marsh, J H, Johnson, S E, Yates, M G and West $\mathrm{Jr}$, D P (2009). Coupling of deformation and reactions during mid-crustal shear zone development: an in situ frictionalviscous transition. Journal of Metamorphic Geology, 27(8), 531-553.

Masci L, Dubacq B, Verlaguet A, Chopin C, De Andrade V, Herviou C (2019) A XANES and EPMA study of $\mathrm{Fe} 3+$ in chlorite: importance of oxychlorite and implications for cation site distribution and thermobarometry. American Mineralogist 104, $403-417$, doi: 10.2138/am-2019-6766 
McWilliams, C K, Wintsch, R P and Kunk, M J (2007). Scale of equilibrium and disequilibrium during cleavage formation in chlorite and biotite-grade phyllites, SE Vermont. Journal of Metamorphic Geology, 25, 895-913.

Morad, S, Sirat, M, El-Ghali, M A K and Mansurberg H (2011). Chloritization in Proterozoic granite from the Aspö Laboratory, southeastern Sweden: record of hydrothermal alterations and implications for nuclear waste storage. Clay Minerals, 46, 495-513.

Muñoz, M, De Andrade, V, Vidal, O, Lewin, E, Pascarelli, S and Susini, J (2006). Redox and speciation micromapping using dispersive X-ray absorption spectroscopy: Application to iron in chlorite mineral of a metamorphic rock thin section. Geochemistry, Geophysics, Geosystems, 7(11), Q11020.

Nishimoto, S and Yoshida, H (2010). Hydrothermal alteration of deep fractured granite: Effects of dissolution and precipitation. Lithos, 115, 153-162.

Parneix, J C, Beaufort, D, Dudoignon, P and Meunier, A (1985). Biotite chloritization process in hydrothermally altered granites. Chemical Geology, 51, 89-101.

Parra, T, Vidal, O and Jolivet, L (2002). Relation between the intensity of deformation and retrogression in blueschist metapelites of Tinos Island (Greece) evidenced by chlorite-mica local equilibria. Lithos, 63, 41-66.

Parry, W T and Downey, L M (1982). Geochemistry of hydrothermal chlorite replacing igneous biotite. Clays and Clay Minerals, 30(2), 81-90.

Pec, M., Stünitz, H. and Heilbronner, R. (2012). Semi-brittle deformation of granitoid gouges in shear experiments at elevated pressure and temperature, Journal of Structural Geology, 38, 200-221.

Pennacchioni, G., Mancktelow, N.S., 2007. Nucleation and initial growth of a shear zone network within compositionally and structurally heterogeneous granitoids under amphibolite facies conditions. Journal of Structural Geology 29, 1757-1780.

Pennacchioni, G., Mancktelow, N.S., 2018. Small-scale ductile shear zones: neither extending, nor thickening, nor narrowing. Earth-Science Reviews 184, $1-12$.

Plümper, O, Botan, A, Los, C, Liu, Y MaltheSørenssen, A and Jamtveit, B (2017). Fluid-driven metamorphism of the continental crust governed by nanoscale fluid flow. Nature geosciences, 10, 685-691.

Pouchou, J-L and Pichoir, F, Heinrich, K F J and Newbury, D E (Eds.) Quantitative Analysis of Homogeneous or Stratified Microvolumes Applying the Model "PAP" Electron Probe Quantitation, Springer US, 1991, 31-75.

Putnis, A (2015). Transient Porosity Resulting from Fluid-Mineral Interaction and its Consequences. Reviews in Mineralogy and Geochemistry, 80, 1-23.

Putnis, A and Austrheim, H (2010). Fluidinduced processes: metasomatism and metamorphism. Geofluids, 10, 254269.

Putnis, A, Timm, J (2010). Replacement processes in the Earth's crust. Elements 6 (3), 159-164.

Putnis, A (2002). Mineral replacement reactions: from macroscopic observations to microscopic

mechanisms. Mineralogical Magazine 66 (5), 689-708.

Raabe, J, Tzvetkov, G, Flechsig, U, Böge, M, Jaggi, A, Sarafimov, B, Vernooij, M G C, Huthwelker, T, Ade, H, Kilcoyne, D, Tyliszczak, T, Fink, R H, Quitmann, C (2008). PolLux: A new facility for soft $\mathrm{X}$-ray spectromicroscopy at the Swiss Light Source, Rev Sci Instrum 79(11).

Rolland, Y and Rossi, M (2016) Two-stage fluid flow and element transfers in shear zones duringcollision burial-exhumation cycle: Insights from the Mont 
BlancCrystalline Massif (Western Alps). J. Geodynamics 101, 88-108.

Rolland, Y, Cox, S F and Corsini, M (2009) Constraining deformation stages in brittleductile shear zones from combined field mapping and ${ }^{40} \mathrm{Ar} /{ }^{39} \mathrm{Ar}$ dating: The structural evolution of the Grimsel Pass area (Aar Massif, Swiss Alps). J. Struct. Geol. 31, 1377-1394.

Rolland, Y, Rossi, M, Cox, S F, Corsini, M, Mancktelow, N S, Pennacchioni, G, Fornari, $\mathrm{M}$ and Boullier, A M (2008) ${ }^{40} \mathrm{Ar} /{ }^{39} \mathrm{Ar}$ dating of synkinematic white mica: insights from fluid-rock reaction in low-grade shear zones (Mont Blanc Massif) and constraints on timing of deformation in the NW external Alps, in: Wibberley, C, Kurz, C A J, Imber, W, Holdsworh, J, Collettini, C (Eds.), The Internal Structure of Fault Zones: Implications for Mechanical and Fluid-Flow Properties. Special Publications of the Geological Society of London, pp. 293-315.

Román-Berdiel, T, Casas, A M, Oliva-Urcia, B, Pueyo, E L and Rillo, C (2004). The main Variscan deformation event in the Pyrenees: new data from the structural study of the Bielsa granite. Journal of Structural Geology, 26, 659-677.

Sanchez, G, Rolland, Y, Schneider, J, Corsini, M, Oliot, E, Goncalves, P, Verati, C, Lardeaux, J M and Marquer, D (2011) Dating low-temperature deformation by 40Ar/39Ar on white mica, insights from Argentera-Mercantour Massif (SW Alps). Lithos 125, 521-536.

Shau, Y-H, Peacor, D R and Essene, E J (1990). Corrensite and mixed-layer chlorite/corrensite in metabasalt from northern Taiwan: TEM/AEM, EPMA, XRD, and optical studies. Contributions to Mineralogy and Petrology, 105, 123-142.

Scheffer, C, Vanderhaeghe, O, Lanari, P, Tarantola, A, Ponthus, L, Photiades, A, France, L (2016). Syn to post-orogenic exhumation of high-grade nappes: structure and thermobarometry of the western AtticCycladic metamorphic complex (Lavrion, Greece). Journal of Geodynamics 96, 174193.

Schmidt, R B, Bucher, K and Stober, I (2018). Experiments on granite alteration under geothermal reservoir conditions and the initiation of fracture evolution. European Journal of Mineralogy, 30, 899-916.
Tenthorey, E and Fitz Gerald, J D (2006). Feedbacks between deformation, hydrothermal reaction and permeability evolution in the crust: Experimental insights. Earth and Planetary Science Letters, 247, 117-129.

Trincal, V and Lanari, P (2016). Al-free ditrioctahedral substitution in chlorite and a ferri-sudoite end-member Clay Minerals, Cambridge University Press, 51, 675-689.

Veblen, D R and Ferry J M (1983). A TEM study of the biotite-chlorite reaction and comparison with petrologic observations. American Mineralogist, 68, 1160-1168.

Vidal, O, De Andrade, V, Lewin, E, Munoz, M, Parra, T, and Pascarelli, S (2006). P-T deformation-Fe3+/Fe2+ mapping at the thin section scale and comparison with XANES mapping. Application to a garnet-bearing metapelite from Sambagawa metamorphic belt (Japan). Journal of Metamorphic Geology 24, 669-683.

Wehrens, P, Baumberger, R, Berger, A and Herwegh, M (2017) How is strain localized in a meta-granitoid, mid-crustal basement section? Spatial distribution of deformation in the central Aar massif (Switzerland). J. Struct. Geol. 94, 47-67.

Wheeler, J. (2014) Dramatic effects of stress on metamorphic reactions. Geology, 42(8), 647-650.

Wibberly, C A J and McCaig, A M (2002). Quantifying orthoclase and albite muscovitization sequence in fault zones. Chemical Geology, 165(3), 181-196.

Wigley, M., Kampman, N., Dubacq, B. and Bickle, M. J. (2012); Fluid-mineral reactions and trace metal mobilization in an exhumed natural $\mathrm{CO}_{2}$ reservoir, Green River, Utah Geology, 40, 555-558.

William, M L, Scheltema, K E and Jercinovic, M J (2001). High-resolution compositional mappinb of matrix phases: implications for mass transfer during crenulation cleavage development in the Moretown Formation, western Massachusetts. 
Journal of Structural Geology, 23, 923939.

Wintsch, R P, Christoffersen, R and Kroneberg, A K (1999). Fluid-rock reaction weakening of fault zones. Journal of geophysical research, 100(B7), 1302113032.

Withney, D and Evans, B (2010). Abbreviations for names of rock- forming minerals. American Mineralogist, 95, 185-187.

Yuguchi, T, Sasao, E, Ishibashi, $\mathrm{M}$ and Nishiyama, $T$ (2015). Hydrothermal chloritization processes from biotite in the Toki granite, Central Japan: Temporal variations of the compositions of hydrothermal fluids associated with chloritization. American Mineralogist, 100, 11341152. 